\title{
Reconstruindo o Mapa das Capitanias Hereditárias
}

\section{Jorge Pimentel Cintra ${ }^{1}$}

RESUMO: Neste artigo, analisa-se o mapa clássico das capitanias hereditárias da América Portuguesa quando foram criadas na primeira metade do século XVI, apontando-se alguns problemas de representação e propondo um novo desenho a partir de fontes primárias como as cartas de doação e forais e a cartografia da época, em particular o mapa de Bartolomeu Velho. As principais alterações propostas referem-se às linhas de divisa nas capitanias do norte, que devem correr segundo meridianos e não segundo paralelos; à particular configuração das capitanias do sul, com linhas dirigindo-se a noroeste; à divisão em quinhões das capitanias de Aires da Cunha e de João de Barros e à existência de terras não distribuídas.

PALAVRAS-CHAVE: Capitanias hereditárias. Mapa das capitanias hereditárias. Cartografia histórica. Brasil. América Portuguesa.

ABSTRACT: This paper analyses the classic map of hereditary captaincies of Portuguese America when it was created, in the first half of the sixteenth century. We point out some of its shortcomings, and propose a new design on primary sources, namely: charts of donation and forais, as well as the cartography of the time, particularly the map of Bartolomeu Velho. The main changes proposed refer to: boundary lines of the northern captaincies, which should follow the meridians and not the parallels; the particular configuration of the southern captaincies, with lines following northwest direction; the division into portions, named quinhões, of the captaincies of Aires da Cunha and Joao de Barros and finally the existence of undistributed lands.

KEYWORDS: Hereditary Captaincies. Map of Hereditary Captaincies. Historic Cartography. Brazil. Portuguese America.

A imagem clássica das Capitanias Hereditárias

Está gravado na memória visual e no imaginário de todos os brasileiros que passaram pelo ensino fundamental o clássico mapa das capitanias hereditárias no momento de sua criação (1534-1536), que as apresenta na forma geométrica
1. Docente da Escola Politécnica da Universidade de São Paulo. E-mail: <jpcintra@usp.br>. O autor agradece à Fapesp pela bolsa de Iniciação científica concedida a Rafael Henrique de Oliveira (2011/01445-0) e ao CNPq pelo financiamento do Projeto Universal de Pesquisa (477.182/2011-9) 
2. Ver Manoel Maurício de Albuquerque (1977). tradicional: partindo de pontos na costa brasileira, as linhas de divisa correm horizontalmente segundo paralelos até encontrar a linha de Tordesilhas. Assim por exemplo aquele que se apresenta na Figura 1, devido a Manoel Maurício de Albuquerque, extraído do Atlas histórico escolar do MEC², utilizado desde 1960 no ensino de história. Mas, conforme se procura mostrar no presente trabalho, essa imagem contém diversas incorreções e pode ser aperfeiçoada.

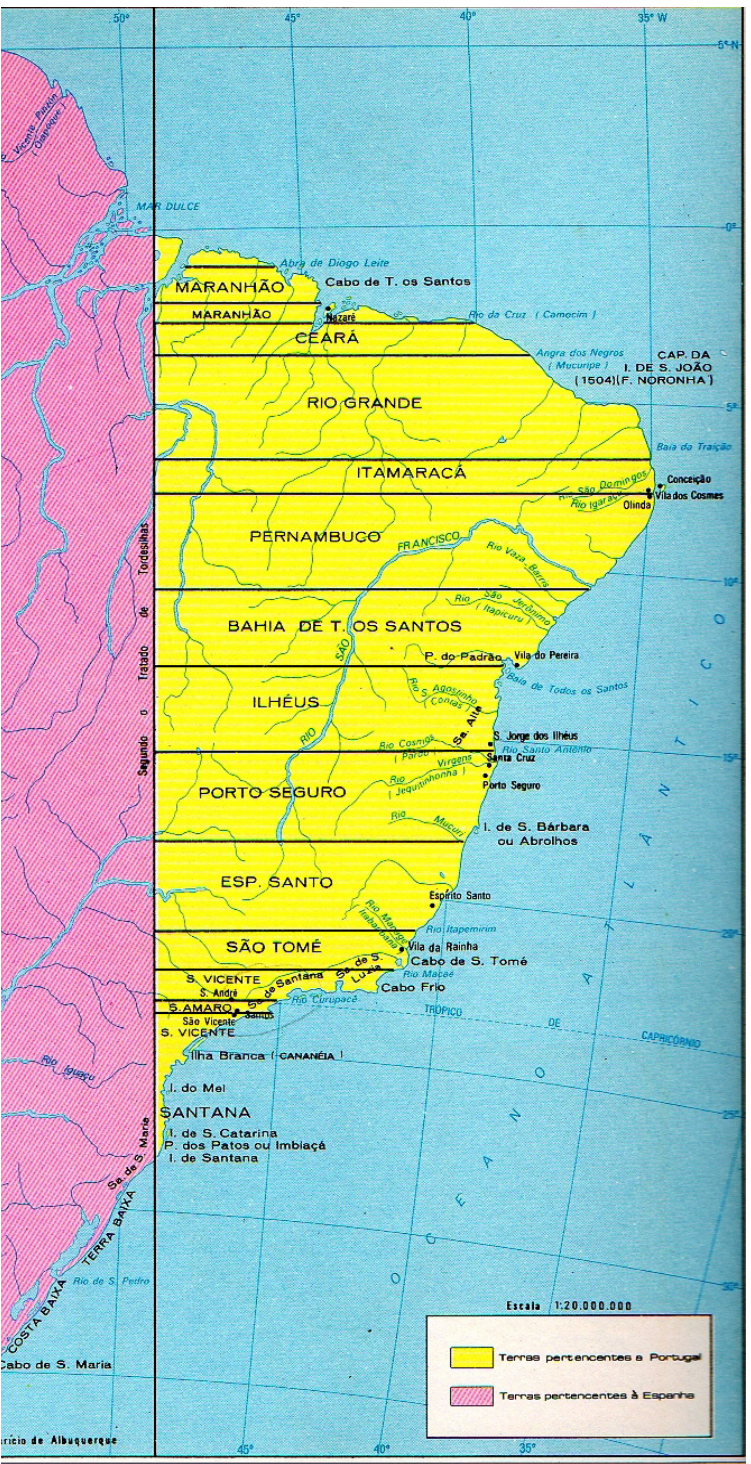

Figura 1 - Mapa das capitanias de autoria de Manoel Maurício de Albuquerque, extraído do Atlas histórico escolar do MEC.

Imagens como essa se repetem à saciedade em obras clássicas, em livros didáticos e na internet, tanto no Brasil como em Portugal. Essas imagens, aliás, não são concordes, divergindo quanto ao nome das capitanias, aos pontos de divisa e outros muitos detalhes. Daí a necessidade de recorrer às fontes para reconstruir um mapa fidedigno. 
Examinando-se o mapa do MEC com cuidado, nota-se que há algumas falhas ou omissões com os quais iniciamos nossa problematização acerca da representação cartográfica das capitanias. Em primeiro lugar, o mapa está em uma projeção (não indicada, mas provavelmente a policônica), em que os meridianos são curvos com a concavidade voltada para o meridiano central da projeção e os paralelos com a concavidade voltada para o pólo sul. Nesse esquema, o meridiano de Tordesilhas deveria ser desenhado com a curvatura correspondente e foi traçado como uma reta, por simplicidade, ao que tudo indica. Esse mapa apresenta de maneira basicamente correta os pontos de fronteira entre as capitanias, mas o Cabo de Todos os Santos está desenhado a oeste da baia do Maranhão quando na realidade situa-se a leste.

Essa peça cartográfica representa corretamente, dentro dessa lógica de divisão, uma porção de terra não distribuída ao norte da primeira capitania na região norte e, portanto, sem nome. No entanto, por coerência, a linha divisória dessa região deveria ser estendida para a llha de Marajó, o que não acontece. Outra pequena falha de finalização é não ter sido desenhada a linha divisória ao sul entre as duas últimas capitanias, correndo aproximadamente pela llha do Mel.

Passemos, então, a examinar o processo de formação dessa concepção de divisão territorial, cujas representações procuramos rever criticamente.

Nota sobre as fontes ou a influência de Varnhagen

O visconde de Porto Seguro, em sua clássica obra História Geral do Brasil $(1854)^{3}$, parece-nos ser a fonte desse ícone cartográfico, visto que já na primeira edição de seu tratado consta uma representação cartográfica entre as páginas 88 e 89 (Figura 2).

Da análise dessa peça e da toponímia presente, pode-se concluir que se trata de um mapa construído sobre uma base cartográfica contemporânea (segunda metade do século XIX), com destaque para a hidrografia, orografia e algumas cidades, sendo que o excesso de detalhes acaba prejudicando a visibilidade das linhas divisórias, finalidade principal almejada. A projeção é a sinusoidal, com paralelos de $5^{\circ} \mathrm{em} 5^{\circ}$, retilíneos, equiespaçados e paralelos ao equador, e com meridianos elipsoidais, com concavidade voltada para o meridiano central do mapa, também graduados de $5^{\circ} \mathrm{em} 5^{\circ}$. $\bigcirc$ meridiano de origem escolhido foi o cabo de Santo Agostinho, na época considerado o ponto extremo leste do Brasil, e a contagem se dá para oeste. $\bigcirc$ meridiano da primitiva demarcação, como o mapa denomina o de Tordesilhas, situa-se nos extremos clássicos: Belém do Pará e Laguna.

Uma legenda no canto inferior direito associa algarismos romanos aos donatários das Capitanias primitivas, começando por Martim Afonso (I) e terminando com Fernando Álvares de Andrade (XII), valendo destacar que, já nessa legenda associa-se de maneira gráfica, colocando-os numa mesma linha, os donatários IX e X: João de Barros e Aires da Cunha.
3. No presente trabalho citamos pela $5^{\mathrm{a}}$ edição da obra $\left(6^{\text {a }}\right.$ do tomo I) de Francisco Adolfo de Varnhagen (1956), mas sempre confrontando com a primeira edição desse volume, de 1854, disponível na Coleção Brasiliana Digital da Universidade de São Paulo. 
Longitude oecidental do Meridiano do Cabo de Santo Agostinho.

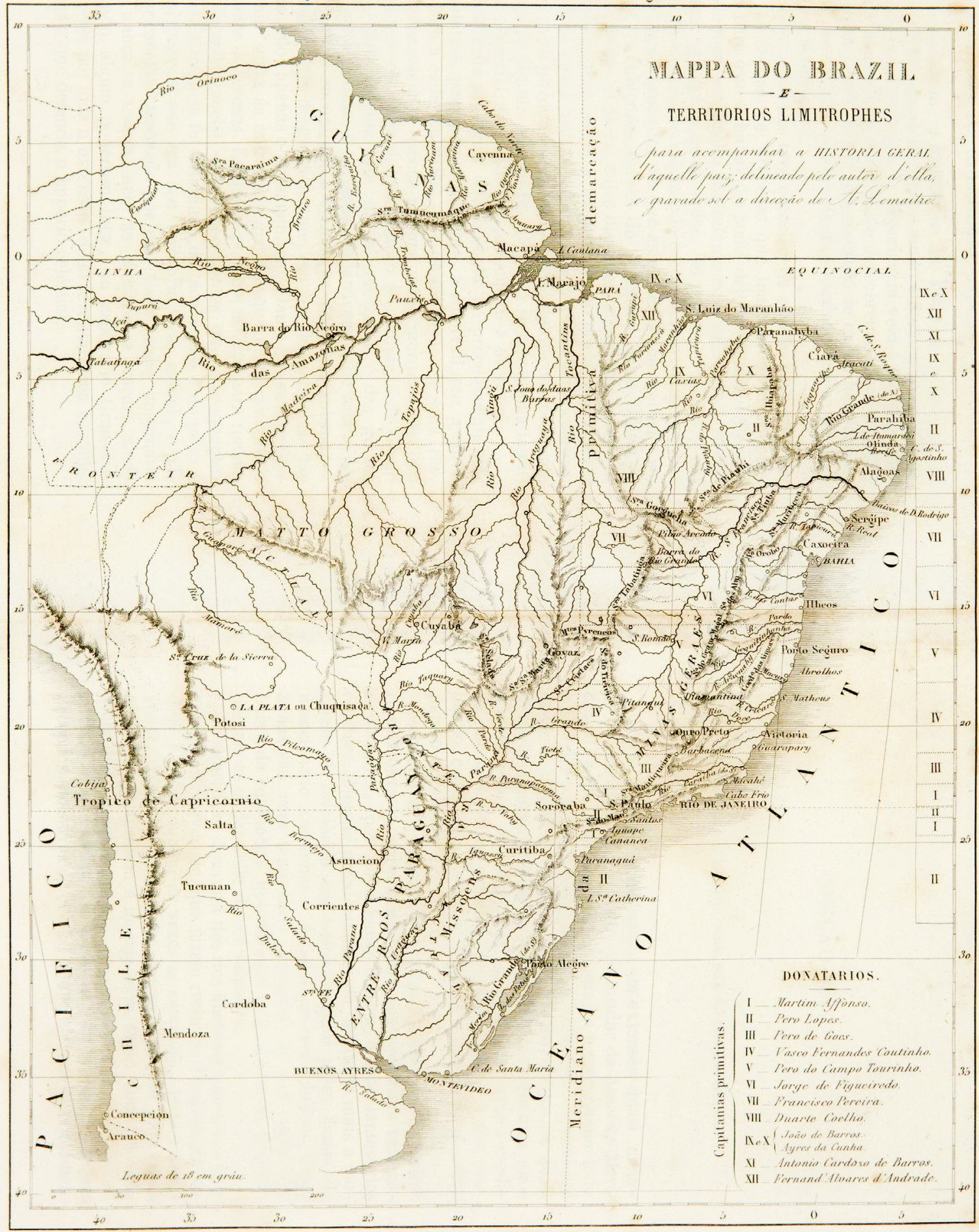

Figura 2 - Mapa das Capitanias Hereditárias proposto por Varnhagen em sua obra clássica História Geral do Brasil, publicada inicialmente em 1854. Acervo da Biblioteca Guita e José Mindlin da Universidade de São Paulo, São Paulo. 
Como apontado, devido à poluição visual e à escala do mapa, não há muito destaque para as linhas divisórias entre as capitanias. Mas essa condição geométrica está também presente através dos algarismos romanos dispostos verticalmente junto à margem direita do mapa: IX e X, XII, XI, etc. Para transmitir melhor essa idéia de faixas horizontais, o autor do mapa situa o mesmo algarismo romano junto à demarcação de Tordesilhas, na mesma altura ou latitude, reforçando a ideia de uma faixa. Algumas dessas linhas, em estilo tracejado, podem ser vistas claramente no mapa original ${ }^{4}$, ainda que haja algumas falhas de desenho.

Essa forma de divisão cartográfica está confirmada por todo o texto da História Geral do Brasil e viria a ser reconhecida elogiosamente por grandes historiadores. Com efeito, Capistrano de Abreu comenta:

\section{Varnhagen precisou nossos conhecimentos sobre os donatários: mostrou como eram em número de doze, deu os nomes de todos, descobriu os forais e cartas de doação de quase todos, traçou os limites das diversas capitanias e calculou as respectivas áreas. O resultado de todas estas investigações fixou lapidarmente do seguinte modo o sábio G. d'Avezac nas Considérations géographiques sur I'histoire du Brésil, 30/31, Paris $1857^{5}$}

Nas revisões e notas a essa clássica obra do historiador sorocabano, tanto Capistrano de Abreu como Rodolfo Garcia confirmam essa divisão territorial brasileira. Diante de tais autoridades não é de estranhar que esse protótipo ganhasse aceitação generalizada.

Por sua vez, o mapa de Luis Teixeira (Figura 3)6, datado de 1586 pelos autores da Portugaliae Monumenta Cartographica7, parece uma prova históricocartográfica do acerto dessa divisão de Varnhagen, que teria simplesmente completado pequenas lacunas.

Mas deve-se notar que esse mapa reflete uma situação posterior ao momento das doações. Como se pode ver, comparando-o com o da Figura 1, há uma série de alterações: a capitania da Bahia já pertencia a Sua Majestade; nas capitanias do norte, unificadas, aparece somente o donatário João de Barros e nas do sul somente Lopo de Sousa; outras capitanias também haviam mudado de dono. Mas com certeza esse mapa inspirou Varnhagen: bastava encontrar os pontos limítrofes das diversas capitanias fundidas em uma só nesse mapa, ao norte e ao sul, e traçar as linhas para oeste. Seu mapa das capitanias apresenta-as com as linhas ao longo de paralelos, ainda que falte alguma na região norte, e fazendo, como se disse, uma indicação dos donatários através de algarismos romanos dispostos verticalmente no Atlântico e no continente, na faixa correspondente a cada capitania.

Mas, como se procurará mostrar, esse autor, sob cuja sombra ainda vivemos, equivocou-se nessa reconstrução e por isso, no presente trabalho, recorrese a fontes primárias: cartas de doação, forais, outros textos originais e mapas da época, para poder avançar no estudo da questão.
4. Devido à largura da página de impressão, a cópia inserida no presente trabalho teve que ser reduzida, dificultando inevitavelmente a visibilidade dessas linhas divisórias.

5. Cf. Capistrano de Abreu (1954). Na sequência, o autor transcreve a descrição das capitanias.

6. A versão apresentada nessa figura foi manipulada em meio digital para melhorar a legibilidade e restaurar as partes rasgadas e dobradas. Paralelamente, quem fez isso, deslocou em cerca de meio grau a escala das latitudes. Para o presente trabalho realizamos medições diretas sobre o fac-símile disponível na Biblioteca da Ajuda, Lisboa.

7. Trata-se da monumental obra de Avelino Teixeira da Mota e Armando Cortesão (1960). 


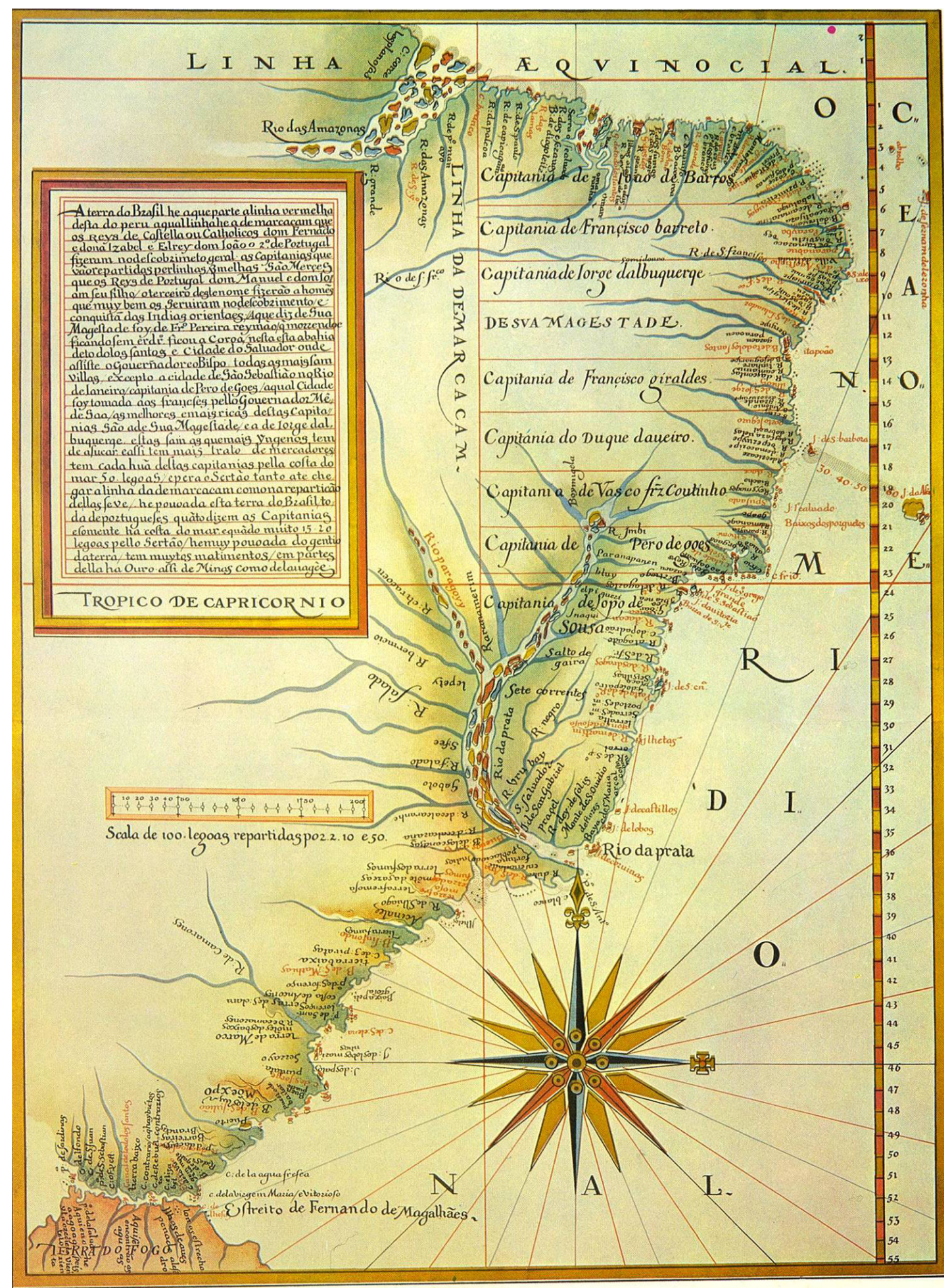

Figura 3 - Mapa das capitanias hereditárias: Carta geral do Brasil, inserida em Roteiro de todos os sinais, de Luís Teixeira, c. 1568. Acervo da Biblioteca Nacional da Ajuda, Lisboa. 
Na Tabela 1 estão indicados os documentos que chegaram até nós, com a data da feitura de cada um.

Tabela 1

Documentos legais das capitanias e datas de assinatura

\begin{tabular}{|c|c|c|c|c|c|}
\hline $\mathrm{n}$ & DONATÁRIO & $\begin{array}{l}\text { CARTA DE } \\
\text { DOAÇÃO }\end{array}$ & FORAL & $\begin{array}{c}\text { OUTROS } \\
\text { DOCUMENTOS }\end{array}$ & LÉGUAS \\
\hline 1 & Aires da Cunha & Parcial & $11 / 03 / 1535$ & \multirow{3}{*}{ 18/06/1535 } & $50+25$ \\
\hline 2 & João de Barros & $8 / 03 / 1535$ & $11 / 03 / 1535$ & & $50+25$ \\
\hline 3 & Fernando Álvares de Andrade & & & & 35 \\
\hline 4 & António Cardoso de Barros & $19 / 11 / 1535$ & $20 / 11 / 1535$ & $13 / 09 / 1535$ & 40 \\
\hline 5 & Duarte Coelho [Pereira] & $10 / 03 / 1534$ & $24 / 09 / 1534$ & $25 / 09 / 1534$ & 60 \\
\hline 6 & Francisco Pereira Coutinho & $5 / 04 / 1534$ & $26 / 08 / 1534$ & $26 / 08 / 1534$ & 50 \\
\hline 7 & Jorge de Figueiredo Correia & & $1 / 04 / 1535$ & & 50 \\
\hline 8 & Pedro do Campo Tourinho & $27 / 05 / 1534$ & $23 / 09 / 1534$ & $7 / 10 / 1534$ & 50 \\
\hline 9 & Vasco Fernandes Coutinho & $1 / 06 / 1534$ & $7 / 10 / 1534$ & $25 / 09 / 1534$ & 50 \\
\hline 10 & Pero de Góis [da Silveira] & $28 / 01 / 1536$ & $29 / 02 / 1536$ & $10 / 03 / 1534$ & 30 \\
\hline 11 & Martim Afonso de Sousa & $20 / 01 / 1535$ & $6 / 10 / 1534$ & $28 / 09 / 1532$ & 100 \\
\hline 12 & Pero Lopes de Sousa & $21 / 01 / 1535$ & $6 / 10 / 1534$ & 28/09/1532 & $50+30$ \\
\hline
\end{tabular}

As cartas de doação, do ponto de vista cartográfico, indicam os limites e as léguas de cada território. As cartas forais indicam o total de léguas conferidas ao donatário, sem especificar se o território é contínuo ou não. Entre os outros documentos, incluem-se os chamados alvarás de lembrança que são documentos de promessa de doação, que existem para os donatários 4 e 10, e uma carta do rei a Martim Afonso, prometendo terras a ele e a seu irmão. Incluem-se também apostilas, que são acréscimos, em geral retificatórios, das cartas de doação dos donatários 5, 6, 8 e 9; e, finalmente, uma carta concedendo a exploração de ouro e prata, num documento conjunto passado aos três primeiros donatários la chamada carta de mineração). Como se verá, esse último documento fornece os limites e as léguas atribuídas a esses capitães, corrigindo ou acrescentando 25 léguas aos dois primeiros e indicando 35 para o terceiro, número sobre o qual há diferentes versões, como se analisará. As células em branco nessa tabela indicam que não se dispõem do referido texto nem de cópia do mesmo.

Para estabelecer esse quadro servimo-nos da obra de Maria José Chorão ${ }^{8}$, pesquisadora que realizou a transcrição paleográfica, a apresentação e 
9. Ver Pedro Taques de Almeida Pais Leme (2004). A obra original é de 1772.

10. Ver Frei Gaspar da Madre de Deus (1975). Como essa edição contém erros na passagem fundamental da definição de limites da capitania, consultamos diretamente o texto da $1^{\mathrm{a}}$ edição (1797) disponível eletronicamente. Além de se achar uma transcrição nessa obra, a carta de doação a Pero Lopes foi publicada também em Documentos históricos da Biblioteca Nacional (1929, 1948) e por António Caetano de Sousa (1739).

11. Ver António Baião (1988, p. XXVIII a XXXIX).

12. Ver Carlos Malheiro Dias (1921).

13. Esse texto em sua essência é do seguinte teor para todas elas: "Faço saber que eu fiz doação e mercê a [nome do donatário e serviços prestados] de [tantas] léguas de terra na minha costa do Brasil, segundo é mais inteiramente e declarado na carta de doação que lhe tenho passado".

14. Carta que El Rei enviou a Martim Afonso, transcrita em Francisco Adolfo de Varnhagen (1956, p. 139140). as notas aos documentos que se encontram na Torre do Tombo, em Lisboa. Nessa apresentação, descreve-se a natureza desses diplomas que constituem os primeiros pilares do ordenamento jurídico brasileiro.

Alguns dados e textos provêm de outras fontes: as Cartas de doação de Martim Afonso de Sousa e de seu irmão procedem das obras clássicas de Pedro Taques $^{9}$ e de Frei Gaspar ${ }^{10}$; a carta de mineração e a carta de doação a João de Barros estão transcritas, ainda que com pequenos erros ou lacunas, na introdução de António Baião à conhecida Ásia desse donatário que foi o cronista das Índias ${ }^{11}$ e também na clássica obra de Malheiro Dias ${ }^{12}$. Nos pontos cartográficos cruciais esses dados foram conferidos com os documentos originais, em pesquisa na Torre do Tombo.

Uma análise das datas de doação permite avançar algumas considerações. Para isso, o conjunto de capitanias será dividido em três grupos: o central (de 5 a 9), o do sul (de 10 a 12) e o do norte (de 1 a 4, acrescido de um lote do donatário 121.

No grupo central a doação ocorreu em ordem perfeitamente cronológica de norte a sul, de março a junho de 1534, podendo-se até inferir a data da doação da capitania 7: abril ou maio desse ano. Mas há uma demora considerável para a doação da capitania 10 (Pero de Góis), com alvará de lembrança de 10/03/1534, mesma data da primeira doação, mas somente efetivada em 28/01/1536, posterior à doação das capitanias 11 e 12 (Martim Afonso e seu irmão). Como se procurará mostrar, esse atraso pode ser devido a um possível estudo de fronteiras, que ao final das contas não foi bem resolvido, pois existe um conflito cartográfico. Feita a doação do quinhão extra (30 léguas) a Pero Lopes de Souza (12), em janeiro de 1535, acima da capitania de Duarte Coelho (5), ficou definida a linha base e fronteira para se começar a divisão das capitanias do norte ( 1 a 4), e vê-se pelas datas das cartas forais e carta de doação que em março desse ano já haviam sido distribuídas algumas dessas terras ( 1 e 2). A existência de um alvará de lembrança (13/09/1535, para o donatário 4) pode indicar também certa dificuldade na divisão dessas capitanias, ocasionando um retraso no documento definitivo (novembro desse ano).

Com relação às cartas forais cumpre notar que por sua natureza devem ser posteriores às cartas de doação, já que especificam direitos e deveres relativos a terras já concedidas. E de fato, todas incluem, no seu primeiro capítulo, a menção a uma doação já feita, informando a quantidade de léguas e remetendo para a descrição dos limites feita no documento anterior ${ }^{13}$. Ora, no caso dos irmãos Sousa isso não acontece: a carta de foral remete a um documento que ainda não havia sido assinado. Deve-se acrescentar que para essas duas não há alvará formal de lembrança, ainda que o rei já houvesse feito, em 28/09/1532, a promessa de 100 léguas a Martim Afonso de Sousa e 50 a seu irmão, nos melhores limites desta costa $^{14}$, quando os dois ainda se encontravam no Brasil. Com a volta a Portugal, em meados de 1533, houve a definição dos locais precisos, com o acréscimo de mais 30 léguas para Pero Lopes (completando as 50 iniciais), precisamente acima 
da Capitania de Duarte Coelho (5). Consultando os documentos de doação, verifica-se que a carta de Pero Lopes ficou pronta em 1/09/1534, mas devido a seu entrelaçamento com a de seu irmão, só foi assinada pelo rei meses mais tarde, no dia seguinte à de Martim Afonso, ou seja, em 21/01/1535.

Outro ponto a frisar é que as cartas forais indicam o total de léguas, sem especificar a divisão em quinhões, como ocorreu no caso dos dois donatários acima considerados e também para Aires da Cunha e João de Barros, ao norte, como se verá.

meridiano de Tordesilhas

Este autor analisou anteriormente a questão da posição dessa linha à vista do texto do Tratado ${ }^{15}$. $O$ resumo da questão é que os pesquisadores da história da cartografia ainda debatem esse tema sem chegar a uma solução definitiva, e isto em função do valor da légua, que na época se exprimia pelo módulo, ou seja, o número de léguas que cabem em um grau de latitude: 16 e 2/3, 17 1/2 ou 18. A Tabela 2 mostra a pluralidade de valores adotados na época da qual nos ocupamos:

\section{Tabela 2}

Diferentes módulos presentes na cartografia ibérica no século XVI16

\begin{tabular}{|c|c|c|c|c|c|}
\hline \multirow[b]{2}{*}{ FONTE } & \multirow[b]{2}{*}{ AUTOR } & \multirow[b]{2}{*}{ DATA } & \multicolumn{3}{|c|}{ MÓDULO } \\
\hline & & & $\begin{array}{c}16 \\
2 / 3 \\
\end{array}$ & $\begin{array}{c}17 \\
1 / 2 \\
\end{array}$ & 18 \\
\hline Esmeraldo de Situ Orbis & Duarte Pacheco Pereira & ca. 1505 & & & $x$ \\
\hline Regimento de Munique & & ca. 1509 & & $x$ & \\
\hline Regimento de Évora & & ca. 1517 & & $x$ & \\
\hline Reportório dos Tempos & Valentim Fernandes & 1518 & $x$ & & $X$ \\
\hline Suma de Geografia & Martin de Enciso & 1519 & $x$ & $x$ & \\
\hline Tratado da Esfera & Francisco Faleiro & 1535 & $x$ & $x$ & \\
\hline Tratado da Esfera & Pedro Nunes & 1538 & & $x$ & \\
\hline Arte de Navegar & Pedro de Medina & 1545 & & $x$ & \\
\hline Tratado da Esfera & João de Castro & 1545 & & $x$ & $x$ \\
\hline Livro de Marinharia & Bernardo Fernandes & ca. 1548 & $x$ & $x$ & \\
\hline Livro de Marinharia & João de Lisboa & ca. 1550 & $x$ & $x$ & \\
\hline Livro de Marinharia & André Pires & ca. 1550 & $x$ & $x$ & \\
\hline Breve Compendio de la Sphera & Martin Cortés de Albacar & 1551 & $x$ & $x$ & \\
\hline De Regulis Instrumentis & Pedro Nunes & 1566 & $x$ & $x$ & \\
\hline
\end{tabular}

No referido trabalho, calculou-se a longitude dessa linha para as duas primeiras hipóteses do valor do módulo e optou-se pela primeira possibilidade, que resulta no valor de $48^{\circ} 35^{\prime}$ (ou em graus decimais: 48,6\%), o que concorda com o
15. Ver Jorge Pimentel Cintra (2012).

16. Os dados da tabela baseiam-se em Joaquim Alves Gaspar (2010) 
17. Cf. Francisco Adolfo de Varnhagen (1956, p. 128).

18. O processo, relativamente complexo para explicar aqui, está muito bem detalhado na obra de Joaquim Alves Gaspar (2010).

19. Ver A.P. Marques (1994).

20. Consulte-se Abrão de Moraes (1984), ou, melhor ainda, o original dessa carta, disponível em Cêurio de Oliveira (1980), ou ainda em meio eletrônico, na wikipedia, em Carta do Mestre João.

21. Duarte Pacheco Pereira, em 1505 (cf.: Barradas de Carvalho, 1991, p. 539) estimava que as terras portuguesas terminavam a $28^{\circ} 1 / 2$. Da leitura do texto de Duarte Pacheco, Jaime Cortesão (1955, p.65, nota 19) afirma, sem base textual que esse autor definia o meridiano de Tordesilhas como passando nesse ponto e na Ilha de Marajó, a $0,5^{\circ}$ de latitude sul. No entanto, é um fato o que menciona logo a seguir: que os cartógrafos portugueses faziam passar essa linha divisória pelas bocas do Amazonas e do Prata.

22. Abra, na cartografia antiga, significa baia ou porto seguro para as naus. Esse mesmo acidente geográfico é denominado em mapas da época como golfo ou B. (Baía) de Diogo Leite.

23. Jaime Cortesão (1955, p. 118-119) considera que essa exploração chegou até a foz do Amazonas, mas que isso não ficou consignado em mapas ou textos em função da política de sigilo de informações cartográficas. cálculo e a posição dessa linha no mapa das capitanias de Varnhagen. Mas esse é um cálculo feito hoje, pois na época não havia métodos nem equipamentos para a determinação precisa da longitude. Por isso, não é correta a afirmação do visconde de Porto Seguro a respeito dos pilotos e cartógrafos de Martim Afonso: "Em terra, esperando, tiveram ocasião de fazer frequentes observações de latitude e longitude do lugar" 17. A latitude media-se através do astrolábio com precisão de $0,3^{\circ}$ a $0,5^{\circ}$, fazendo observações ao sol ao meio dia, e, por isso, se fosse verdade a afirmação que faz logo a seguir de que "no vizinho porto de Cananéia, onde nunca se vira o sol durante 44 dias", teria sido impossível medir a latitude.

Já a longitude era avaliada por léguas percorridas, na direção lesteoeste e transformadas para graus e compatibilizadas com as latitudes, medidas de maneira independente e tidas sempre como corretas ${ }^{18}$. Para a avaliação dessas léguas, era necessário contar com a experiência dos pilotos e com suas regras empíricas, como, por exemplo, o Regimento das léguas documento em uso a partir do século XV que indicava como calcular as distâncias percorridas na prática da navegação e que fornecia: para 24 horas, com vento tenso em popa, de 36 a 38 léguas; com vento, quando a nau governa pela bolina, 8 léguas. Como a nau andava em ziguezague, era necessário efetuar as reduções através de regras práticas fornecidas por esse Regimento ${ }^{19}$. A conta das léguas percorridas começava nas thas de Cabo Verde e estas se iam acumulando e os pilotos de cada nau faziam seus cálculos e conferiam periodicamente com os demais. É isso o que se vê, por exemplo, no primeiro documento de nossa cartografia, a Carta de Mestre João, que vinha na esquadra de Cabral ${ }^{20}$.

Martim Afonso, por meio de seus pilotos, também realizou suas contas e o fato de as terras distribuídas terminarem num ponto de latitude de $28^{\circ} 1 / 3$ é um indício de que esse ponto estaria próximo dos limites das terras portuguesas e mais ou menos por aí passava a famosa linha de Tordesilhas ${ }^{21}$. Com essa latitude podese entrar num mapa atual e calcular a longitude desse ponto $\left(48,7^{\circ}\right)$, que se aproxima muito do valor acima indicado $\left(48^{\circ} 35^{\prime}\right.$ ou $\left.48,6^{\circ}\right)$, algo que nos parece devido a uma simples coincidência e não à precisão com que se mediam as longitudes, mesmo porque essa latitude de $28^{\circ} 1 / 3$ possui uma incerteza em torno do $0,5^{\circ}$, que se reflete na longitude. Por sua parte, os pilotos das duas naus de Diogo Leite, enviados por Martim Afonso para explorar a costa norte, estimaram que - limite com Castela passava pela abra ${ }^{22}$ que leva o nome desse capitão ${ }^{23}$. Como se mostrará mais adiante, esse ponto corresponde à foz do rio Turiaçú, que possui a longitude de $45,2^{\circ}$ (e não 48, $6^{\circ}$ ); ou seja, os pilotos de Martim Afonso estimaram para o dito meridiano duas posições diferentes, uma ao norte e outra ao sul. Essas estimativas valiam para efeito de distribuição de terras (ad intra), pois, para mapas públicos (ad extra), o meridiano passava na foz do rio Amazonas e pelo estuário do rio da Prata, como se vê por exemplo no mapa de Luis Teixeira, já apresentado na Figura 2. Isso também supõe um erro ou distorção cartográfica (conhecida como distensão da costa leste-oeste), pois as duas localidades não estão sobre o mesmo meridiano. E isso, não por razões cartográficas, mas por política de estado que 
data do tempo de D. Manuel (pelo menos desde 1519)24. Assim, embora para efeitos externos a linha passasse por esses dois pontos, as terras, ad cautelam, só foram distribuídas até os limites avaliados pela expedição de Martim Afonso: os $28^{\circ}$ 1/3 ao sul e a abra de Diogo Leite ao norte. Assim, um mapa das capitanias desenhado hoje teria uma porção de terra sem distribuição ao norte, entre esse último local e a linha de Tordesilhas.

\section{protótipo de mapa do Brasil e os cálculos das léguas das capitanias}

Como destaca Armando Cortesão ${ }^{25}$, o centro oficial da cartografia portuguesa era o Armazém da Guiné e da Índia, em Lisboa, onde trabalhavam numerosos cartógrafos. Das inúmeras referências, deduz-se que havia um protótipo (um planisfério ou mapa mundi), em que se iam registrando as novas descobertas com a abundante toponímia, que às vezes era alterada pelo rei, como se vê inclusive em alguma das cartas de doação. A partir desse mapa, faziam-se as cópias, as chamadas cartas de marear, que eram levadas pelos pilotos nas navegações. Sobre estas, eram traçadas as rotas e acrescentados os novos lugares descobertos e nomeados pelo capitão da frota. Na volta das viagens, os mapas assim anotados serviriam de base para atualizar a carta padrão. A anterior ficava, pois, desatualizada e talvez isso, além do terremoto de Lisboa e a política de sigilo de informação cartográfica, ajude a explicar a sobrevivência de relativamente poucos mapas portugueses dessa época. Esse processo de construção de mapa, que era válido para a África e a Índia, estendeu-se com certeza para o Brasil.

Assim, pode-se imaginar um cartógrafo debruçado sobre um mapa do Brasil, sem distorções propositais ${ }^{26}$, na tarefa de dividir as capitanias de acordo com as diretrizes reais, combinando o número de léguas estabelecido para cada uma com a toponímia existente, para assim tentar fixar os pontos de limite na costa (de preferência, acidentes geográficos) e produzir um memorial descritivo para ser incorporado à carta de doação.

Como se fixariam as coordenadas dos pontos da costa? Conforme apontado acima, as latitudes eram medidas por meio do astrolábio, com maior precisão em terra do que no mar, e, nos mapas portugueses, desenhava-se uma escala para essa coordenada geográfica (cf. mapa de Luis Teixeira, Figura 2), mas o mesmo não acontecia com relação às longitudes. No transporte em alto mar, o valor dessa coordenada era calculado como se indicou acima; mas ao longo da costa o processo devia ser diferente, sendo, provavelmente, da seguinte maneira: escolhia-se o ponto de origem lo mais a leste possível, por exemplo, o cabo de Santo Agostinhol, media-se a latitude de partida e arbitrava-se sua longitude. A seguir, navegava-se ao longo da costa la certa distância para não encalhar na areia e evitar as reentrâncias) medindo o rumo e as léguas através da força do vento, de acordo com as mesmas regras de alto mar. Na sequência, projetava-se graficamente esse trecho nas direções norte-sul e leste-oeste, obtendo-se as diferenças de latitude e longitude com relação ao ponto de partida. E da mesma maneira para os demais
24. Ver Jaime Cortesão (1955, p.65).

25. Ver Armando Cortesão (1960, p. 166 e ss).

26. A morfologia do que seria esse mapa pode ser buscada examinando os mapas coetâneos que situem os topônimos citados nas diversas cartas de doação nas correspondentes latitudes: Baía da Traição $\left(6^{\circ}\right)$, Angra dos Negros $\left(2^{\circ}\right)$ e do rio da Cruz $\left(2^{\circ} 1 / 3\right)$. Apesar de ser de 1934, e ser um mapa protótipo, o de Gaspar Viegas não atende a essas condições morfológicas de latitude e, além disso, como todo mapa público da época distende a costa brasileira de leste a oeste colocando a foz do rio da Prata e do rio Amazonas no mesmo meridiano. Esse mapa está disponível no acervo digital da Biblioteca Nacional. Cf. Gaspar Viegas (1534). 
27. É o que em Direito, até hoje, se chama venda ou doação ad corpus: os limites e confrontações são conhecidos e formam parte integrante e principal da descrição; a referência dimensional tem interesse secundário e é de caráter meramente enunciativo.

28. Por exemplo, na carta de doação a Pero de Góis lê-se: "porém não havendo dentro no dito limite e demarcação as ditas trinta léguas eu não lhe serei obrigado a lhas satisfazer; e havendo mais ficará com tudo o que mais for". Cf. Maria José M.B.Chorão (1999, p. 27).

29. Ver IBGE (1999)

30. Ver texto na nota 28 trechos; até que se chegava a um novo ponto de latitude conhecida ou medida e procedia-se a um ajuste, se necessário. A esses erros, na medição durante a navegação, devem ser somados aqueles devidos à medição sobre a carta protótipo para delimitar as léguas de cada capitania.

O ideal, na descrição dos lotes nas cartas de doação, seria indicar, como limites extremos de cada uma, pontos conhecidos e inquestionáveis na costa (um rio, uma baía) e incluir uma cláusula dizendo que a quantidade de léguas resultante seria a existente entre esses dois pontos e indicar uma quantidade aproximada de léguas ${ }^{27}$. Isso foi feito em alguns $\operatorname{casos}^{28}$, mas não foi possível para todas as capitanias, principalmente por não se conhecer com detalhe a costa brasileira. O cartógrafo (ou equipe) fez o melhor que pôde, com os conhecimentos disponíveis na época, incluindo os novos dados trazidos por Martim Afonso.

Para o presente trabalho, realizou-se uma avaliação da distribuição das léguas, não sobre mapas da época (frequentemente distorcidos), mas sobre mapas ałuais, já que se pretendeu fazer uma avaliação da posição, tamanho e fronteiras reais das capitanias. Utilizou-se o mapa do Brasil na escala de $1: 1.000 .000$, elaborado pelo IBGE, órgão responsável pela cartografia oficial do Brasil29. A medição foi feita traçando linhas poligonais contínuas próximas à costa, simulando a navegação, sem se aproximar muito da praia e sem percorrer os meandros das baías. Foram feitas diversas medições e foram calculados os valores médios.

A seguir, serão analisados em detalhe as capitanias, seus limites, léguas e fronteiras, seguindo a proposta acima, de obedecer a uma ordem cronológica e agrupar didaticamente por conjuntos de capitanias - centrais, do sul e do norte - que possuem grau de dificuldade crescente de montagem do mosaico, tanto pelos conceitos cartográficos envolvidos como pela falta ou incongruência de dados.

As capitanias centrais

A Tabela 3 apresenta as capitanias identificadas por um número (coluna n) os donatários, as léguas, o limite ao norte nas cartas de doação e o local a que corresponde num mapa atual. Para saber o limite sul basta consultar o limite norte da capitania seguinte.

Essas capitanias e seus limites estão desenhados na Figura 4. A descrição de limites, tanto hoje como na época, exige a feitura prévia de um esboço cartográfico completo, o que se comprova pelo fato de que, no mesmo dia em que se passa a primeira carta (Duarte Coelho, 5), passa-se também uma promessa de doação da última capitania desse grupo (Pero de Góis, 10) e, diga-se de passagem, especificando 30 léguas e não 50, como para a maioria (foi o que sobrou), e fazendo a ressalva de que poderia ser menos do que isso ${ }^{30}$. As siglas derivam dos nomes da Capitanias (Figura 4). 
Tabela 3

Capitanias centrais: donatários, léguas e limite com a capitania ao norte

\begin{tabular}{|c|c|c|c|c|c|}
\hline $\mathrm{n}$ & DONATÁRIO & SIGLA & LÉGUAS & $\begin{array}{l}\text { LIMITE COM A } \\
\text { CAPITANIA AO } \\
\text { NORTE NA CARTA } \\
\text { DE DOAÇÃO }\end{array}$ & $\begin{array}{l}\text { LOCAL ATUAL / } \\
\text { INTERPRETAÇÃO }\end{array}$ \\
\hline 5 & Duarte Coelho [Pereira] & PE & 60 & $\begin{array}{c}\text { Rio da Santa } \\
\text { Cruz }\end{array}$ & $\begin{array}{l}\text { Canal ao sul da llha de } \\
\text { Itamaracá }\end{array}$ \\
\hline 6 & Francisco Pereira Coutinho & BA & 50 & $\begin{array}{l}\text { Rio de São } \\
\text { Francisco }\end{array}$ & Rio de São Francisco \\
\hline 7 & $\begin{array}{l}\text { Jorge de Figueiredo } \\
\text { Correia }\end{array}$ & IL & 50 & $\begin{array}{c}\text { Ponta sul da baía } \\
\text { de Todos os } \\
\text { Santos }\end{array}$ & $\begin{array}{c}\text { Sul da baía de Todos os } \\
\text { Santos }\end{array}$ \\
\hline 8 & Pedro do Campo Tourinho & PS & 50 & $\begin{array}{l}\text { Fim da anterior } \\
+50 \text { léguas }\end{array}$ & Rio Pardo \\
\hline 9 & Vasco Fernandes Coutinho & ES & 50 & $\begin{array}{l}\text { Fim da anterior } \\
+50 \text { léguas }\end{array}$ & Rio Mucuri \\
\hline 10 & Pero de Góis [da Silveira] & ST & 30 & $\begin{array}{l}\text { Baixos dos } \\
\text { Pargos }\end{array}$ & Rio Itapemirim \\
\hline
\end{tabular}

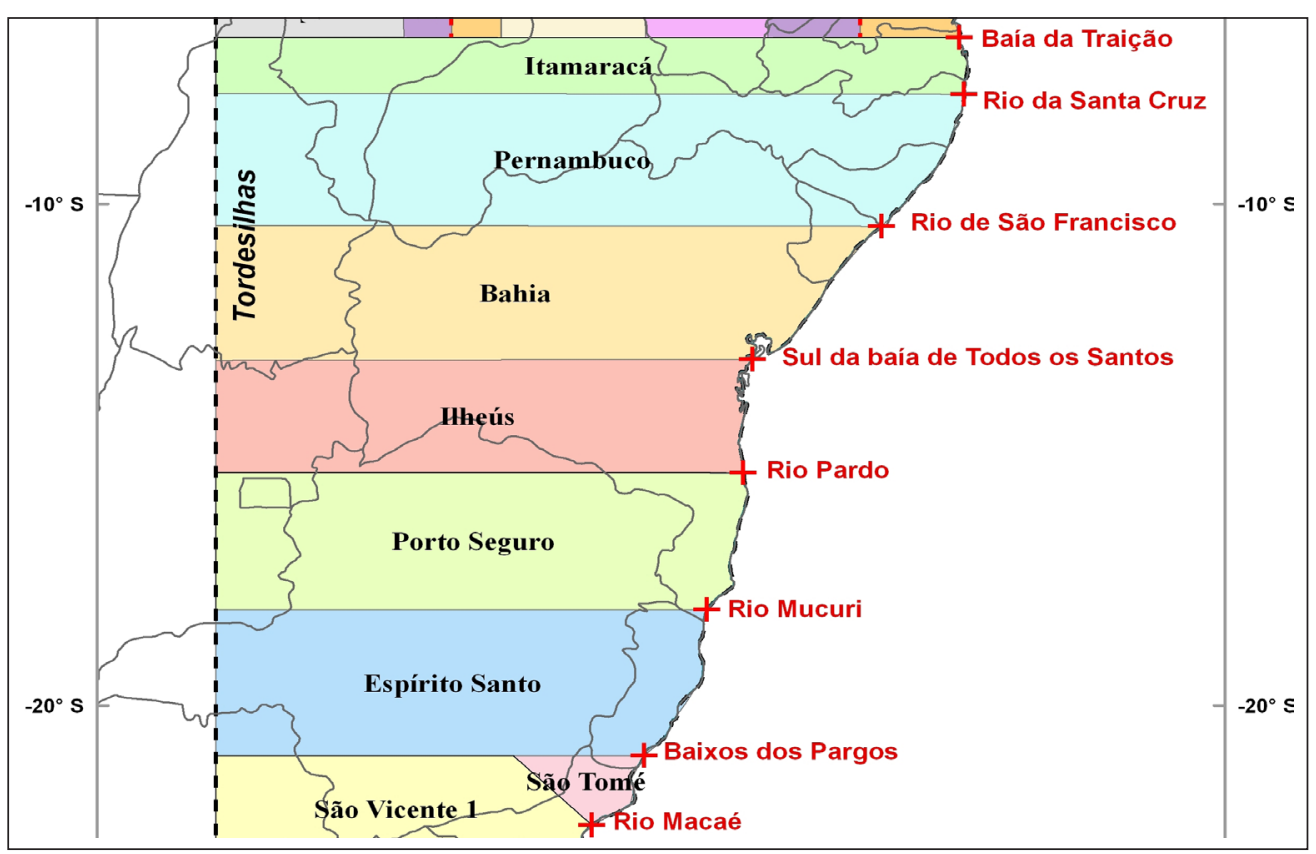

Figura 4 - Esquema das capitanias centrais. Desenho do autor.

A divisão e as cartas começam pela de Duarte Coelho (5), fixando os limites ao norte e ao sul através de acidentes geográficos. $\bigcirc$ mesmo aconteceu com a capitania seguinte, de Francisco Pereira Coutinho (6), mas a partir daí só se especificam 50 léguas para cada donatário (7, 8, e 9), sem indicar nenhum local 
31. Ver capítulo Baixos de Pargas e Santa Catharina das Mós em Alberto Lamego (s/d).

32. Ver Francisco Adolfo de Varnhagen (1956, p. 198). Este acordo foi confirmado pela carta régia de 12/03/1543. nos textos de doação, a menos do último ponto, que é o acidente geográfico denominado Baixos dos Pargos. Os dois limites intermediários, rio Pardo e rio Mucuri, foram estimados pelas léguas e fixados mais tarde. Os Baixos dos Pargos, provavelmente, não seria um local muito bem definido ${ }^{31}$, já que os donatários vizinhos fixaram como divisa o rio ltapemirim, por mútua convenção, em meados de 153632; esse local situa-se muito aproximadamente, na latitude de $23^{\circ}$, como se infere do mapa de Luis Teixeira (Figura 2) e como se pode comprovar no mapa atual do IBGE, com o qual se trabalhou.

Uma vez fixados esses pontos, podem ser feitas algumas considerações e análises cartográficas, iniciando-se pela análise das léguas, conforme a tabela abaixo:

\section{Tabela 4}

Capitanias centrais: léguas de cada uma: na carta de doação, na realidade (testada) e na largura da faixa

\begin{tabular}{c|l|l|c|c|c|c}
\multirow{2}{*}{$n$} & \multirow{2}{*}{ DONATÁRIO } & \multirow{2}{*}{ CAPITANIA } & \multicolumn{4}{|c}{ LÉGUAS } \\
\cline { 4 - 7 } & & & Doação & Testada & Diferença & Largura \\
\hline $12 A$ & Pero Lopes de Sousa & Itamaracá & 30 & 19,1 & $-10,9$ & 18,8 \\
5 & Duarte Coelho [Pereira] & Pernambuco & 60 & 51,7 & $-8,3$ & 44,9 \\
6 & Francisco Pereira Coutinho & Bahia & 50 & 60,8 & 10,8 & 43,9 \\
7 & Jorge de Figueiredo Correia & Ilhéus & 50 & 39,3 & $-10,7$ & 37,0 \\
8 & Pedro do Campo Tourinho & Porto Seguro & 50 & 49,8 & $-0,2$ & 45,5 \\
9 & Vasco Fernandes Coutinho & Espírito Santo & 50 & 55,4 & 5,4 & 48,5 \\
\hline 10 & Pero de Góis [da Silveira] & São Tomé & 30 & 31,9 & 1,9 & 23,0 \\
\hline
\end{tabular}

Nessa tabela, a coluna $n$ indica o número atribuído ao donatário, numa sequência de norte para sul; a letra adicional, quando pertinente, descrimina o lote do donatário. A coluna doação indica as léguas que figuram na carta de doação; a coluna testada, as léguas medidas ao longo da costa no mapa atual, pelo processo anteriormente descrito, que simula tanto um navio andando nas proximidades da costa quanto o processo de medição sobre um mapa; a coluna diferença, como o nome indica, apresenta o quanto a doação foi inferior ou superior à realidade. Finalmente, a coluna largura corresponde à distância entre as linhas paralelas, transformada de graus para léguas. Todos os cálculos foram feitos considerando o módulo de 16 2/3 léguas por grau. 
Para prosseguir nessa análise, é preciso ter em conta que os termos de doação, no primeiro capítulo da carta, sempre trazem um texto padrão do seguinte teor: "as ditas [valor numérico] léguas de terra se estenderão e serão ao longo da costa e entrarão na mesma largura pelo sertão e terra firme adentro, tanto quanto puderem entrar e for da minha conquista". Ora, a expressão "ao longo da costa" indica que a medida deve ser feita obedecendo à inclinação geral da costa, correspondendo à coluna que denominamos testada.

Pela coluna diferença vê-se que capitanias 8 e 10 estão bem ajustadas, isto é, a diferença entre o prometido e o realizado consiste em um erro relativamente pequeno. Uma (9) tem erro de cerca de 5 léguas, outra (6) de cerca de 10 léguas a mais do que o prometido e as outras (12A, 5 e 7) tem cerca de 10 léguas a menos. Isso mostra a margem de erro dessa distribuição.

Parece-nos que essas diferenças podem ser explicadas pelas deficiências e imprecisões do mapa sobre o qual as medições foram feitas; um erro de 0,5 graus, que poderia ocorrer nos dois extremos, corresponde a mais de 8 léguas. Para verificar essa hipótese, foram feitas, com a ajuda de um programa para cartografia digital, medições sobre o mapa de Luis Teixeira e a análise mostrou que esse mapa possui algumas deficiências, além da dilatação da costa norte: a primeira linha divisória que devia passar pela Baía da Traição passa por um ponto que se situa a $0,7^{\circ}$ acima dessa posição ${ }^{33}$; a linha seguinte, que deveria passar pela itha de Itamaracá, está situada em Olinda, e assim por diante. Com isso, diminuem-se as testadas de Itamaracá e de Pernambuco e aumenta-se a da Bahia. A conclusão geral é que uns são os valores nominais e outros os reais das léguas concedidas e que o erro pode estar na casa das 10 léguas, o que é muito, tanto para as capitanias de 50 léguas (20\%), quanto para a de 30 (33\%).

Por outro lado, rejeita-se a hipótese de que a medida das léguas deveria ser feita entre os paralelos, isto é, de que corresponderia à coluna largura na Tabela 4, iá que isso levaria a diferenças ainda maiores. Pode-se continuar a análise focando a expressão acima citada: "serão ao longo a costa e entrarão na mesma largura pelo sertão e terra firme adentro", tomada ao pé da letra isso é um impossível cartográfico, a menos dos casos em que a costa tenha orientação norte-sul, única situação em que a testada é igual à largura. Parte da expressão "entrarão pela mesma largura pelo sertão" pode, no entanto, querer significar que as linhas divisórias são paralelas, mantendo a largura no sertão. Isso, somado à expressão "se porá um padrão das minhas armas e do dito padrão se lançará uma linha cortando a loeste pela terra firme adentro" permite concluir que todas as linhas correm segundo paralelos geográficos. Deve-se destacar, para ser usado mais adiante, que a expressão para oeste (ou loeste) só aparece nas cartas de doação das capitanias da Bahia e Itamaracá; o que, no entanto pela condição da largura constante, é suficiente para garantir que todas essas divisas seguem os paralelos terrestres.
33. A carta de doação de Pero Lopes de Sousa, no texto de Pedro Taques (2004; 1772), situa a Baía da Traição na latitude de $5^{\circ}$. Já o texto de Frei Gaspar da Madre de Deus (1975; 1797) indica $6^{\circ}$ para esse mesmo ponto. Na realidade situa-se a $6,7^{\circ}$. Esse erro de $0,7^{\circ}$ corresponde a umas 12 léguas, o que explica em parte uma doação de 10,9 léguas a menos que as 30 prometidas. 
As capitanias do sul

Continuando a análise de forma similar, apresenta-se a seguir a Tabela 5 com as léguas e limites entre as capitanias desse outro grupo:

Tabela 5

Capitanias do sul: donatários, léguas e limites com as capitanias vizinhas

\begin{tabular}{|c|c|c|c|c|c|}
\hline $\mathrm{n}$ & DONATÁRIO & SIGLA & LÉGUAS & $\begin{array}{c}\text { LIMITE COM A } \\
\text { CAPITANIA AO NORTE } \\
\text { NA CARTA DE } \\
\text { DOAÇÃO }\end{array}$ & $\begin{array}{l}\text { LOCAL ATUAL / } \\
\text { INTERPRETAÇÃO }\end{array}$ \\
\hline 10 & Pero de Góis [da Silveira] & ST & 30 & Baixos dos Pargos & Rio Itapemirim \\
\hline $11 \mathrm{~A}$ & Martim Afonso de Sousa & SV1 & 55 & $\begin{array}{c}13 \text { léguas ao norte de } \\
\text { Cabo Frio }\end{array}$ & Rio Macaé \\
\hline $12 B$ & Pero Lopes de Sousa & SA & 10 & $\begin{array}{c}\text { Rio Curupacé / } \\
\text { Curparê }\end{array}$ & Rio Juquiriquerê \\
\hline $11 \mathrm{~B}$ & Martim Afonso de Sousa & SV2 & 45 & $\begin{array}{l}\text { Rio de São Vicente, } \\
\text { barra do norte }\end{array}$ & Barra da Bertioga \\
\hline $12 \mathrm{C}$ & Pero Lopes de Sousa & ST & 40 & $\begin{array}{l}12 \text { léguas ao sul da } \\
\text { Ilha de Cananéia }\end{array}$ & $\begin{array}{l}\text { Barra sul de } \\
\text { Paranaguá }\end{array}$ \\
\hline * & Fim das terras distribuídas & & & $\begin{array}{l}\text { Terra de Santa Ana a } \\
\qquad 28^{\circ} 1 / 3\end{array}$ & $28^{\circ} 1 / 3$ \\
\hline
\end{tabular}

Nessa tabela, o significado das colunas é o mesmo da Tabela 3. Com relação à interpretação dos locais de divisa, já se mencionou, no exame do grupo anterior, a fixação por consenso do rio Itapemirim entre os donatários vizinhos. A barra do rio Macaé foi estabelecida mais tarde, por meio de medições sobre mapas ou in loco. O rio Curupacé (ou em outra grafia Curparê) corresponde ao atual Juquiriquerê, nas proximidades de Ilhabela. A Barra de São Vicente corresponde ao terceiro braço de mar no lagamar de Santos e São Vicente (aquele que está mais ao norte e corresponde à barra da Bertioga): no texto da carta de doação a Pero Lopes de Souza, apresentado por Frei Gaspar, está muito clara a expressão da banda do norte que permite a fixação; já no texto apresentado por Pedro Taques lque é fruto de uma cópia ou translado modificado intencionalmente), essa e outras expressões foram omitidas, dando pé a interpretações divergentes que foram usadas na querela entre os descendentes dos irmãos Sousa. A fixação da Barra sul de Paranaguá ou llha do Mel depende da medição das 12 léguas ao sul de Cananéia. $\bigcirc$ último ponto situa-se no encontro do paralelo $28^{\circ} 1 / 3$ com a costa do Brasil e não corresponde a nenhum acidente geográfico de maior relevo: está a meio caminho entre as atuais Imbituba e Laguna (Santa Catarina). Em função da precisão com que se mediam 
latitudes $\left(0,3^{\circ}\right.$ a $\left.0,5^{\circ}\right)$ essa posição pode variar. Essas capitanias e seus limites estão desenhados na Figura 5:

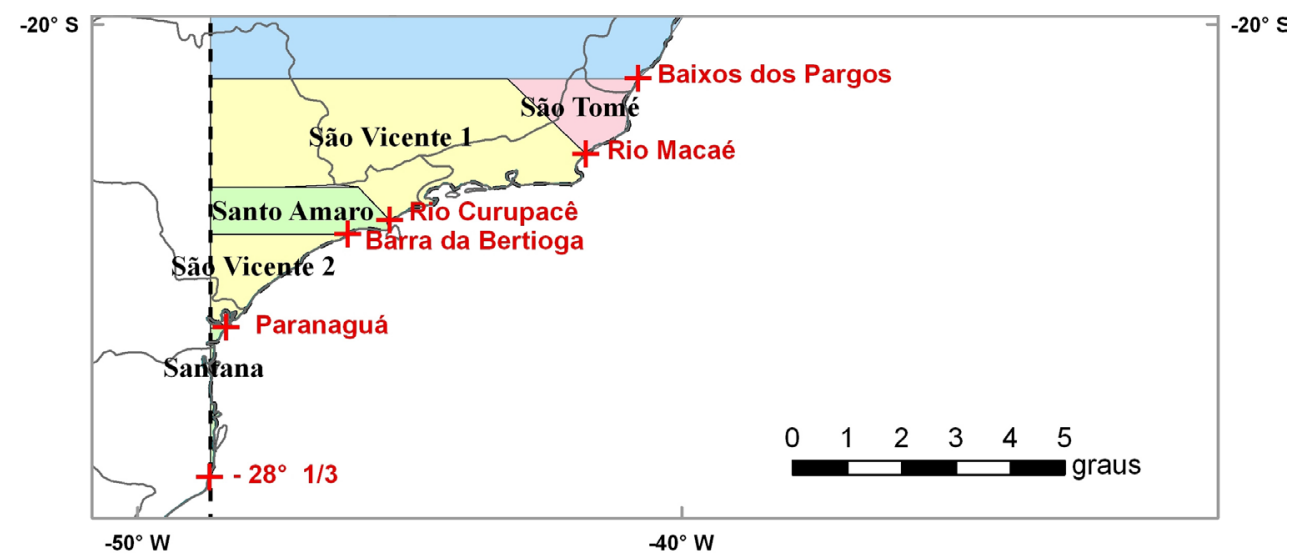

Figura 5 - Esquema das capitanias do sul. Desenho do autor.

A seguir foi montada a Tabela 6 , análoga à 14 , e com o mesmo significado para as colunas:

Tabela 6

Léguas de cada capitania: na carta de doação, na realidade (testada) e na largura da faixa

\begin{tabular}{c|l|c|c|c|c|c}
\hline \multirow{2}{*}{$n$} & \multicolumn{1}{|c|}{ DONATÁRIO } & CAPITANIA & \multicolumn{4}{|c|}{ LÉGUAS } \\
\cline { 4 - 7 } & Doação & Testada & Diferença & Largura \\
\hline 10 & Pero de Góis [da Silveira] & São Tomé & 30 & 31,9 & 1,9 & 23,0 \\
\hline 11A & Martim Afonso de Sousa & São Vicente 1 & 55 & 64,5 & 9,5 & 22,2 \\
\hline 12B & Pero Lopes de Sousa & Santo Amaro & 10 & 14,1 & 4,1 & 2,5 \\
\hline 11B & Martim Afonso de Sousa & São Vicente 2 & 45 & 43,8 & $-1,2$ & 28,2 \\
\hline 12C & Pero Lopes de Sousa & Santana & 40 & 45,9 & 5,9 & 45,1 \\
\hline
\end{tabular}

A análise da mesma, e, em concreto, da coluna diferença, mostra que o valor da testada corresponde relativamente bem, para quase todas as capitanias, ao valor nominal da carta de doação, sendo que os lotes 11 A e 12B excedem o valor do documento legal, em benefício dos donatários, notadamente para o lote A de Martim Afonso. O valor da largura corresponde à distância entre os paralelos traçados pelos limites da costa (como na Figura 1) e mostra de forma acentuada o efeito da inclinação geral da costa nesta região. No entanto, deve-se ter em conta a largura variável em alguns desses lotes (Figura 5), como se comentará logo mais. 
34. Frei Gaspar (1975, p. 202-203).

35. Esse texto e os demais são extraídos de Frei Gaspar da Madre de Deus, na edição original de 1797 , pois versões recentes omitem trechos e enganamse em números; algo também crítico nos textos apresentados por Pedro Taques.

36. Cf. Francisco Adolfo de Varnhagen (1956, p. 147).

37. Isso confirma as qualidades de cartógrafo desse donatário, indicadas pelo próprio visconde de Porto Seguro e confirmadas por seus comentaristas, Capistrano de Abreu e Rodolfo Garcia. Cf. Francisco Adolfo de Varnhagen (1956, p. 128 e nota 10).
Uma interessante medição do lote 12B (10 léguas), realizada em 1624, vem narrada por Frei Gaspar: ocorreu por ocasião da conhecida controvérsia entre - Conde de Monsanto e a Condessa de Vimieiro para dirimir uma questão sobre os limites de suas capitanias. Foram contratados quatro pilotos, com suas naus, para medirem essa testada entre o rio Curupacé e a Barra de Bertioga e o resultado foi que, com cálculos independentes, esses pilotos juraram sobre os Evangelhos e todos juntos em altas vozes disseram que eram 10 léguas esforçadas, até 12 pelas suas cartas $^{34}$, o que é relativamente compatível com as 14,1 medidas sobre um mapa atual (Tabela 6).

Mas a partir desse ponto começam as mudanças sugeridas pelo presente trabalho, perceptíveis na Figura 5, pelas linhas que correm a noroeste.

Para entender o traçado dessas linhas de divisa, divergentes do desenho tradicional, é interessante acompanhar o texto da carta de doação ${ }^{35}$ que descreve os limites ao norte do primeiro lote de Martim Afonso. [No rio Macaé] "se porá um padrão das minhas armas, e se lançará uma linha pelo rumo de noroeste até a altura de vinte e um graus, e desta dita altura se lançará outra linha, que virá diretamente a l'oeste". No trecho acima, grifou-se a expressão noroeste, para contrapor à expressão a oeste que consta em outras cartas de doação (Bahia e ltamaracá). Então, a linha segue uma direção de $45^{\circ} \mathrm{com}$ a horizontal (noroeste), encontra o paralelo de $21^{\circ}$ da capitania de Pero de Góis num ponto de inflexão e, a seguir, corre para oeste.

O limite inferior é deduzido igualmente do texto que vem logo a seguir: "e se porá outro padrão da banda do norte do dito rio Curupacé, e se lançará uma linha pelo mesmo rumo de noroeste até a altura de vinte e três graus, e desta altura cortará a linha direitamente a l'oeste" (grifou-se também a expressão chave). Ou seja, segue uma trajetória semelhante à anterior.

Essa maneira de lançar as divisas visava sem dúvida aumentar a largura e a área das Capitanias de Martim Afonso de Sousa e de seu irmão, precisamente naquelas regiões em que a direção da costa tornaria a largura das faixas muito pequena, se as linhas corressem diretamente para oeste, como se vê na conformação equivocada da Figura 1. O visconde de Porto Seguro, e com ele seus seguidores, destaca a exiguidade da faixa assim traçada em virtude do rumo e que "desse modo a capitania de Martim Afonso, que talvez o doador pensou fazer maior que as outras, saiu das mais pequenas [...] da ignorância dos princípios científicos procedem resultados absurdos" 36 . Contrariamente a essa afirmação, esse donatário sabia, por certo, o que estava fazendo e por isso estipulou as divisas inclinadas, correndo a noroeste e aumentando a faixa e a área de sua capitania: foi uma solução bem pensada e mostra que o donatário conhecia bem o rumo da costa nessa região ${ }^{37}$.

Além da inusitada conformação (triangular) da capitania 10 (São Tomé, de Pero de Góis), surge a questão de compatibilizar seu limite ao sul, na confrontação com Martim Afonso. Para evitar problemas, a descrição da raia nesse limite deveria ser exatamente a mesma que a de seu vizinho: uma linha partindo do rio Macaé 
(ou seja, 13 léguas ao norte do Cabo Frio), com rumo noroeste até o paralelo $21^{\circ}$ e a seguir correndo para oeste por essa linha geográfica. Mas a carta de doação de Pero de Góis transcreve simplesmente a expressão padrão "entrarão na mesma largura pelo sertão e terra firme adentro tanto quanto puderem entrar e for de minha conquista", ou seja, sugere a interpretação que é comum para todas as capitanias anteriores: uma linha correndo diretamente a oeste, como aconteceu no mapa de Luís Teixeira (Figura 2), que ignora o rumo a noroeste dessa divisa. Isso poderia provocar lifígios, caso se fosse proceder a uma demarcação ou mesmo um desenho das mesmas sobre um mapa, a partir do texto das cartas de doação. Mas não houve confronto nem demarcação de limites, a menos do estabelecimento de alguns pontos ao longo da costa. Em caso de litígio, parece-nos que prevaleceria de fato a linha divisória indicada na carta de doação de Martim Afonso, por haver indicação explícita da mesma, e de acordo com ela foi feito o desenho da presente proposta. A complexidade dessas divisas pode ter sido a causa do atraso da carta de doação de Pero de Góis, que tinha um alvará de lembrança anterior; isso aliado ao fato de ele ter ficado no Brasil e ter regressado tardiamente a Portugal para cuidar pessoalmente dos aspectos jurídicos de seus direitos.

Antes de passar ao exame das capitanias do norte, podem ser ressaltados dois pontos: o primeiro deles é que a carta de doação do lote mais ao sul (Santana, de Pero Lopes de Sousa), estabelece o limite na altura dos já ditos $28^{\circ} 1 / 3$ e indica que nesse ponto se porá um padrão e se lançará uma linha que corra a loeste ${ }^{38}$, sem indicar o ponto de término, isto é, sem incluir a expressão "até os limites de meus domínios". Ou seja, admitia-se que a linha divisória com Castela poderia estar a oeste desse ponto. No entanto, manteve-se no desenho a linha passando por aí, numa longitude de $48,7^{\circ}$. Ampliando o mapa dessa região poderia ver-se que essa capitania tem uma faixa de terra muito estreita; inclusive a linha meridiana entra no mar em alguns pontos, criando um território descontínuo.

O outro ponto são as consequências dessa divisão entre os dois irmãos: ela colocaria dentro das terras de Pero Lopes de Sousa le de seu descendente, o conde de Monsanto) vilas como São Paulo, Santana de Parnaíba, Sorocaba, Itu, Jundiaí, Guarulhos, Mogi das Cruzes, São José dos Campos, isto para falar só das mais antigas. Ou seja, ninguém atentou ou se preocupou por lançar no terreno as linhas previstas nas cartas de doação; considerava-se que essas vilas faziam parte de São Vicente e seus fundos, isto é aquelas terras às quais se acedia a partir dos caminhos que partiam da marinha.

As capitanias do norte

Inicialmente, na citada carta a Martim Afonso, o rei pretendia distribuir as terras de Pernambuco ao rio da Prata. Talvez porque de Pernambuco para o sul fosse a zona do pau-brasil e dos melhores portos, a região norte parecia menos favorecida: costa com baixios de areia, correntes, ventos traiçoeiros, marés muito movimentadas, menos portos ${ }^{39}$.
38. Uma má transcrição desse texto em Pedro Taques dá a entender que a linha correria (só) 10 léguas para oeste. $\mathrm{Na}$ realidade essas 10 léguas referem-se à testada do lote desse donatário encravado nas terras de seu irmão.

39. No mapa de Diogo Ribeiro (1529), na costa nordeste do Brasil lê-se: "nesta costa, desde o rio Doce [Amazonas] até o cabo de São Roque, não se achou coisa de proveito, e depois de visitada uma ou duas vezes, logo que foi descoberta, não se voltou mais a ela". Cf.: Capistrano de Abreu (1956, p. 192) e também o mapa de Diogo Ribeiro (1529). 
40. Comparando esse texto com outras cartas e supondo uma extensão semelhante, estimou-se a porcentagem faltante: $37 \%$ no início (pouco menos de 2 páginas) e $16 \%$ ao final (meia página), sobrando $47 \%$ do documento original (2 páginas).

41. Examinando o documento e comparando com outros, estima-se que faltam umas 25 linhas no início e umas 53 ao final, num total de 295; ou seja, dispõe-se de $74 \%$ do documento e a parte remanescente contem os dados cartográficos de interesse, para conferir com a transcrição de Baião (1988).

42. Ver António Baião (1988, p. XXIX).
Mas, iniciado o processo de doação a partir de Pernambuco para o norte, surgiram novos pretendentes às terras. Antes de proceder a isso, o rei fez doação de mais um lote de 30 léguas a Pero Lopes (Itamaracá) e por cima dessa linha procedeu-se à divisão de terras pelos quatro pretendentes (capitanias 1 a 4 na Tabela 1).

Nesse grupo de capitanias do norte, faltam as cartas de doação de Fernando Álvares de Andrade e de Aires da Cunha, sendo que existe um fragmento da carta deste último, correspondendo a cerca de $50 \%$ do documento ${ }^{40}$, e o que sobra não contem informação cartográfica relevante. Por sua vez, costuma-se dizer que a carta de doação de João de Barros foi perdida, ou que sobram só fragmentos, o que não é verdade. Esse documento encontra-se transcrito na citada introdução de António Baião ao Ásia de João de Barros e, por outro lado, boa parte dela encontra-se na Torre do Tombo ${ }^{41}$.

\section{A carta de doação de minérios}

De sumo interesse é a chamada carta de mineração que, num documento único, concede direitos e porcentagens na mineração de ouro e prata aos três primeiros donatários: Aires da Cunha, João de Barros e Fernando Álvares de Andrade. Esse texto levou alguns autores a interpretar que o rei havia feito uma doação de terras sob regime de condomínio, parceria ou senhorio múltiplo; em alguns casos 100 ou 150 léguas para Aires da Cunha e João de Barros; em outros 185 ou 225 para os três donatários. Mas as cartas forais, uma para cada donatário, não permitem essa interpretação: os direitos e poderes são de tal natureza amplos e fortes que impossibilitam dois ou mais senhores sobre um mesmo território. $O$ documento concede direitos sobre ouro e prata na capitania de cada qual, assim como se concediam direitos sobre outros produtos nas cartas de doação e forais. Pode-se falar sim em uma exploração inicial conjunta do território entre os três, que foi o que de fato se tentou.

No tocante às léguas de cada donatário, as cartas forais dos dois primeiros (Aires da Cunha e João de Barros) especificam 50 léguas para cada um; não se dispõem do foral de Fernando Álvares de Andrade, e a de António Cardoso de Barros, além de fornecer os limites, especifica dois valores contraditórios para a testada da capitania: 50 léguas (provavelmente por cópia mecânica dos dizeres iniciais repetitivos de outra carta de doação) e 40 léguas, valor que se repete por duas vezes no mesmo documento e que coincide com o valor da carta de foral.

A carta de doação de João de Barros esclarece não só os dados da sua como da de Aires da Cunha: "ordenei ... duas capitanias de cem léguas [no total, subentende-se] e a cada uma cinqüenta léguas ... [e as] ditas cem léguas ... as hão de repartir entre si igualmente de tal maneira que cada um deles fique com sua capitania de 50 léguas" e mais abaixo: "segundo a repartição que ... entre si fizerem das ditas cem léguas ${ }^{42}$. Ou seja, não havia uma linha demarcatória entre os dois donatários e deixava-se a eles a liberdade de dividir o território das cem 
léguas e fixar os limites internos dos quinhões, que poderiam ser vários para cada um, respeitando o total de 50 para cada qual. Ao final declara que "a Aires da Cunha mandei dar outra tal [carta de doação] das outras cinqüenta léguas de sua capitania". Esse documento fixa o limite ao sul como sendo o final das 30 léguas de Pero Lopes de Sousa, mas não fixa um ponto ao norte, somente dizendo: "[as terras] correrão para a dita banda do norte ao longo da costa quanto couber nas ditas cem léguas".

Assim, a carta de mineração vem a ser documento fundamental para algumas questões. Em primeiro lugar, fica-se sabendo que "todos três juntamente estão contratados e concertados por minha licença [para] que misticamente povoem e aproveitem como melhor puderem por espaço de vinte anos e que no fim deles as repartam entre si como thes parecer da maneira que cada um fique com aquela parte que the couber pela repartição que assim fizerem". Ou seja, os limites não foram fixados a priori no momento da doação, mas dava-se a liberdade da escolha de lotes em função da futura descoberta de ouro e prata, ficando a obrigação de informar ao rei, ao cabo de 20 anos, as fronteiras entre eles acordada. E divisão não ocorreu, como se sabe, pelas vicissitudes e desventuras do empreendimento comum. Uma repartição desse tipo, já contemplada para os dois primeiros donatários, ficaria um pouco mais complicada em função da inclusão de mais um protagonista e pelo fato das terras não serem contínuas, em função do lote de um quarto donatário las 40 léguas de António Cardoso de Barros) estar encravado nessas terras.

A seguir vem a questão das léguas das capitanias nesse documento. Começa-se por enunciar o total que cabe as esses três donatários: "duzentas e vinte cinco léguas ... repartidas em capitanias", e a seguir indica-se a parcela de cada um: "ao dito Fernão Dalvares trinta e cinco léguas ... e aos ditos Ayres da Cunha e Joam de Barros, cento e cinqüenta léguas". E, nesse ponto, começam as questões: esse documento atribui a esses dois donatários, 50 léguas a mais do que as 100 mencionadas na carta de doação a João de Barros (ou mesmo na soma das cartas forais): "cinqüenta léguas que começam na abra de Diogo Leite da banda de loeste e se acabam no cabo de todos los santos da banda do leste do Rio Maranhão, segundo é mais declarado nas cartas de doação". Essas 50 léguas não figuram nas cartas de doação nem nas forais; é um acréscimo, que poderia ser resolvido juridicamente com uma apostila às cartas de doação e às forais, mas não se tem notícia disso.

Outra questão com relação às léguas é que a soma total (225) não coincide com as parcelas: $35+150=185$, ou seja, faltam 40 léguas. Para compatibilizar os números, uma alternativa é imaginar que cartógrafo real enganou-se nas léguas de Fernando Álvares de Andrade e somar as 40 léguas faltantes às 35 desse donatário, chegando ao valor de 75 léguas, o que o igualaria aos outros dois donatários. Essa é a solução estabelecida por Varnhagen. No entanto, cabe pensar em outra possibilidade: o cartógrafo, estudando as capitanias do norte para estabelecer o total, somou entre as parcelas as 40 léguas da capitania de António Cardoso de Barros, encravada entre essas. Para dirimir a questão, pode-se recorrer ao original da Torre do Tombo ${ }^{43}$, reproduzido na Figura 6. Lendo e interpretando com 
43. CHR-L-1-21_C0151: ANTT, Chancelaria Régia, D. João III, Livro21, folha 73.

44. Foram examinados os mapas do Portugaliae Monumenta Cartographica e os das mapotecas de: Torre do Tombo, Biblioteca Nacional, Biblioteca da Ajuda, Arquivo Ultramarino, Biblioteca da Academia de Ciências de Lisboa (em Lisboa) e Biblioteca do Ministério das Relações Exteriores / Palácio Itamaraty e Biblioteca Nacional (no Rio de Janeiro).

45. Ver Jaime Cortesão (1965, p. 360 e ss; 2009). atenção esses números pode-se verificar que o total está correto (225), bem como as 150 léguas dos dois primeiros donatários, mas há uma particularidade no trecho que indica as léguas de Fernando Álvares de Andrade: quem escreveu ou transcreveu esse documento enganou-se e rabiscou o valor que tinha escrito (começo da linha 7). Após o rabisco pode-se ler "trinta cinco léguas", que foi a leitura de António Baião e a que se fez, de maneira independente por várias pessoas para o presente trabalho; mas emendando as últimas letras rabiscadas com o trinta cinco, pode-se confundir com sasenta cinco (65), valor que aparece na citada obra de Malheiro Dias, ou forçando um pouco mais, setenta cinco (75). À margem do documento pode-se ler claramente o número 75, aí colocado por mão desconhecida, talvez do próprio visconde de Porto Seguro. Mas definitivamente, a leitura mais clara é 35. Esse número, como se verá, ajusta-se melhor ao valor efetivo medido sobre uma carta.

Qualquer que seja a solução, ela não modifica o desenho das capitanias, pois esse documento fornece também os diversos pontos fronteiriços das capitanias.

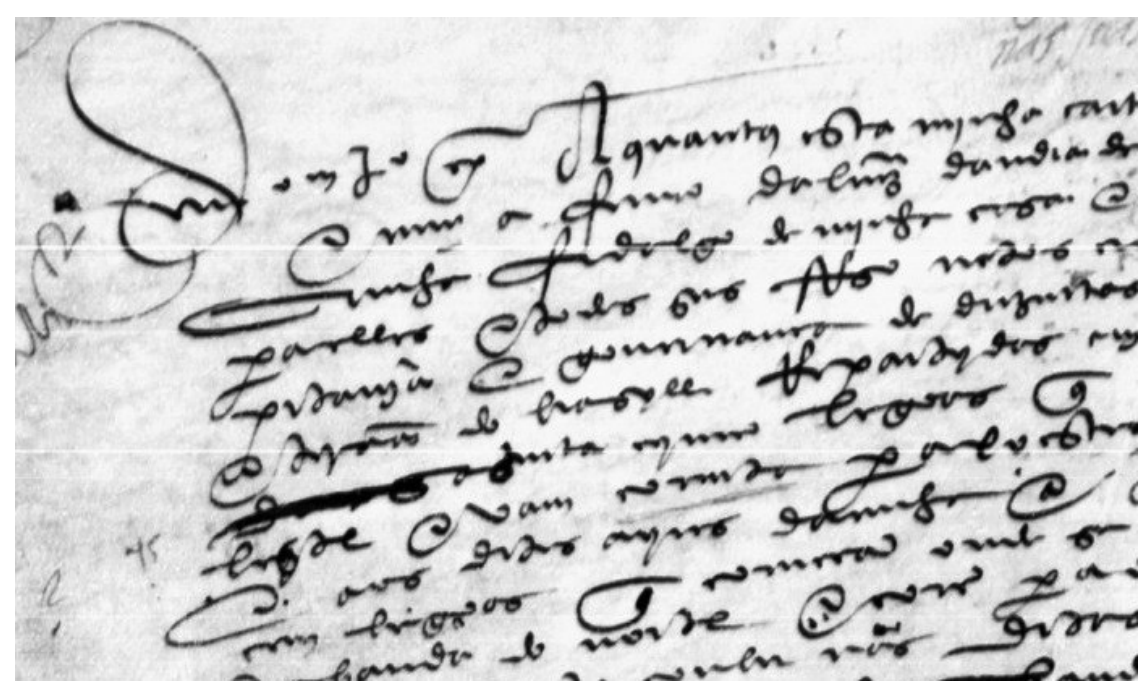

Figura 6 - Trecho da carta de mineração, decisivo para a determinação das léguas de Fernando Álvares de Andrade. Notar o número 75 colocado à margem e a palavra riscada. Acervo da Torre do Tombo, Lisboa, reprodução do autor.

mapa de Bartolomeu Velho e as divisas ao longo de meridianos

Para prosseguir no estudo e montar o quebra-cabeça, recorreu-se ao mapa de Bartolomeu Velho (1561), reproduzido na Figura 7. Esse documento é o único, entre os mapas conhecidos e analisados na presente pesquisa ${ }^{44}$, que traz as capitanias nessa forma, em data próxima do momento da partilha. Foi analisado por Jaime Cortesão45, que o explora bastante à luz de seu conhecido mote, a "Ilha Brasil", mas não o examina sob o ponto de vista das informações sobre as capitanias. Da mesma forma, Armando Cortesão e Avelino Teixeira da Mota, em sua monumental obra conjunta, examinam essa peça cartográfica, mas não sob esse ângulo. 


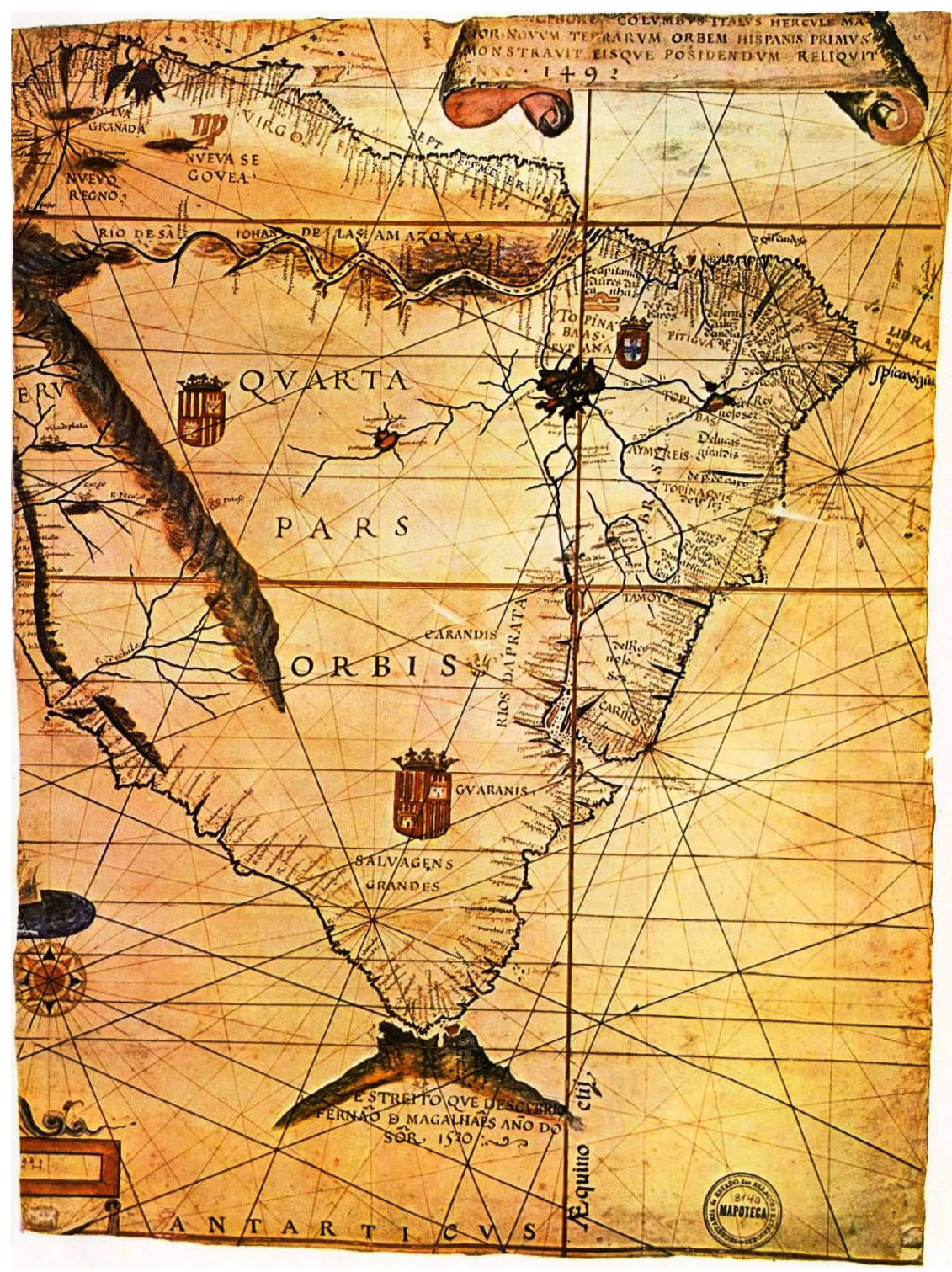

Figura 7 - Mapa de Bartolomeu Velho, 1561, original pertencente ao Museu Naval de La Spezia, Reprodução do fac-simile da mapoteca do Ministério das Relações Exteriores. Retirado da obra Mapas Históricos Brasileiros, São Paulo. Abril Cultural, 1969. Reprodução do autor.

Deixando de lado inúmeros outros aspectos, esse mapa ajuda a identificar a ordem com que as capitanias aparecem. Nessa figura, o fato de ser reduzida, em função da largura da página, dificulta a leitura, mas no fac-símile da Biblioteca do Itamaraty lê-se claramente, de oeste para leste em blocos separados: "capitania d aires da cunha / de j de baros / de fernan dalvz dandrade / de at ${ }^{\circ}$ cardoso / de aires da cunha / de johão de barros / de po lopes de sousa, etc. terminando ao sul do Brasil com um: del Rey noso Sor". 
46. Esses valores retratam uma situação em que a costa, em direção a oeste, se afasta do equador, quando na realidade ela se aproxima. As latitudes a oeste e leste estão equivocadas $\left(2,3^{\circ}\right.$ e $\left.2^{\circ}\right)$ e não coincidem com as latitudes do mapa de Gaspar Viegas $\left(1,7^{\circ}\right.$ e $\left.1,6^{\circ}\right)$, nem com as atuais $\left(3,7^{\circ} \mathrm{e}\right.$ $\left.2,9^{\circ}\right)$
Isso confirma as informações da carta de mineração: lotes conjugados de Aires da Cunha e de João de Barros, um par na região do Maranhão, outro na região do Rio Grande do Norte. As outras duas capitanias não apresentam divisões em lotes, mas são em território contínuo.

No entanto, esse mapa prolonga as capitanias do norte para além da abra de Diogo Leite, até a foz do Amazonas, e ao sul, vê-se na obrigação de colocar uma outra capitania (Del Rey Nosso Senhor) para prolongar os domínios portugueses até essa linha divisória que, por sinal, corta o continente bem abaixo da foz do rio da Prata. Sendo um mapa público, ad extra, os limites não podiam ser pontos próximos ao Maranhão e Laguna, mas empurrados para a linha que passava próximo à foz dos dois grandes rios.

Outra conclusão decorre da forma como os nomes estão grafados: não em linhas horizontais mais ou menos paralelas à costa, como aconteceria se o esquema fosse o do mapa tradicionalmente veiculado nos livros didáticos (Figura 1), mas em trechos que ocupam faixas verticais acompanhando os meridianos, em direção ao sul e não a oeste. Isso leva a inferir que as linhas divisórias são meridianos e não paralelos.

Outro indício muito forte dessa solução provém do exame da carta de doação a João de Barros: "as quais cinqüenta léguas se estenderão e serão de largo ao longo da costa e entrarão na mesma largura pelo sertão e terra firme adentro tanto quanto puder entrar e for de minha conquista que não sejam por mim provido a outro capitão". Essa última expressão aqui grifada seria dispensável se as linhas corressem para oeste, pois nessa direção não encontrariam nenhuma outra capitania, mas sim a linha de Tordesilhas e as terras de Castela. Só há problema se as linhas corressem na direção sul, pois nesse caso encontrariam as terras de Itamaracá, doadas a Pero Lopes de Sousa.

Outra razão para essa solução é a que decorre do exame das latitudes dos pontos de divisa mencionados na carta de doação de António Cardoso de Barros: "começam da Amgra dos Negros que está da banda de leste em altura de dois graus e acabam no rio da Cruz da banda de loeste que está em altura de dois graus e um terço". A Figura 8 é um esboço dessa situação ${ }^{46}$.

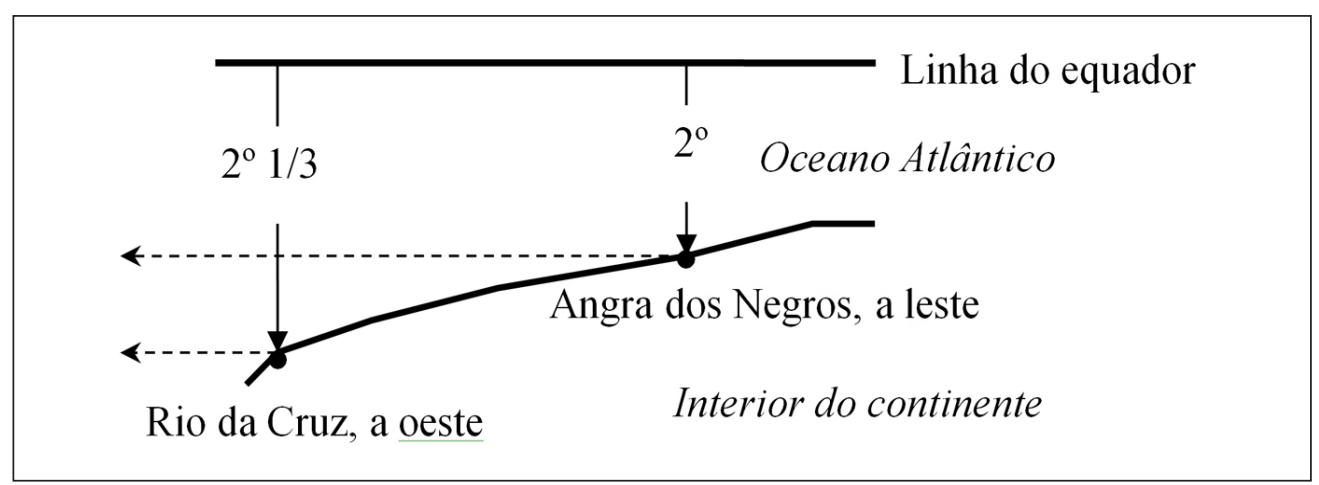

Figura 8 - Esquema da capitania de Antonio Cardoso de Barros. Desenho do autor. 
Por essa figura vê-se que, se as linhas de divisa, a partir dos pontos fronteiriços, corressem para oeste, o donatário só teria um pedaço de mar com a largura de $1 / 3$ de grau (umas 6 léguas), o que é um absurdo. Os autores, seguindo o visconde de Porto Seguro, costumam inverter, pelo menos mentalmente, as latitudes dos pontos para que a capitania tenha a forma de uma pequena faixa de terra com essa largura: "Esta capitania tinha apenas 6 léguas em espaço de latitude" 47.

\section{Os limites entre as capitanias e a proposta de desenho}

Com relação aos limites entres as capitanias, os três primeiros de leste a oeste, ou seja, a Abra de Diogo Leite, o Cabo de todos os Santos la leste do rio Maranhãol e o rio da Cruz, figuram na carta de mineração. $\bigcirc$ visconde de Porto Seguro cita os dois primeiros entre aspas, mas não indica a fonte ${ }^{48}$. $\bigcirc$ ponto seguinte, Angra dos Negros, figura na carta de doação a António Cardoso de Barros e coincide com o ponto onde terminam as cem léguas dos dois primeiros donatários. Estas, como se viu, começavam na Baía da Traição. Dispõe-se assim dos dados para desenhar o esquema dessas capitanias (Figura 9); montar um quadro com esses limites (Tabela 7) e realizar o cálculo das léguas (Tabela 8), coisas que ajudam a entender melhor o esquema.

Nessa figura, foram situados os pontos divisórios (Tabela 7) e foi feita a hipótese de que os lotes 1A e 2A resultam de uma partição ao meio lentre a Abra de Diogo Leite e o Cabo de Todos os Santos) procurando igualar as larguras e testadas (23,2 e 20, 1 léguas). E algo semelhante, entre a Angra dos Negros e a Baia da Traição, resultando em duas faixas verticais de igual largura e área aproximadamente igual, ainda que isso resulte em valores bastante diferentes para as testadas na costa (37,3 e 50, 1 léguas), pois o lote RN2 (de esquina) possui duas laterais na costa. Como se trata de uma divisão não feita na época das doações, nem depois, as linhas divisórias foram desenhadas em tracejado, somente para indicar que essas terras deveriam ser repartidas entre os dois donatários; mas não se fixaram pontos na costa como limites, para não transmitir a impressão de que seriam pontos que figuram na partição feita pelo rei.

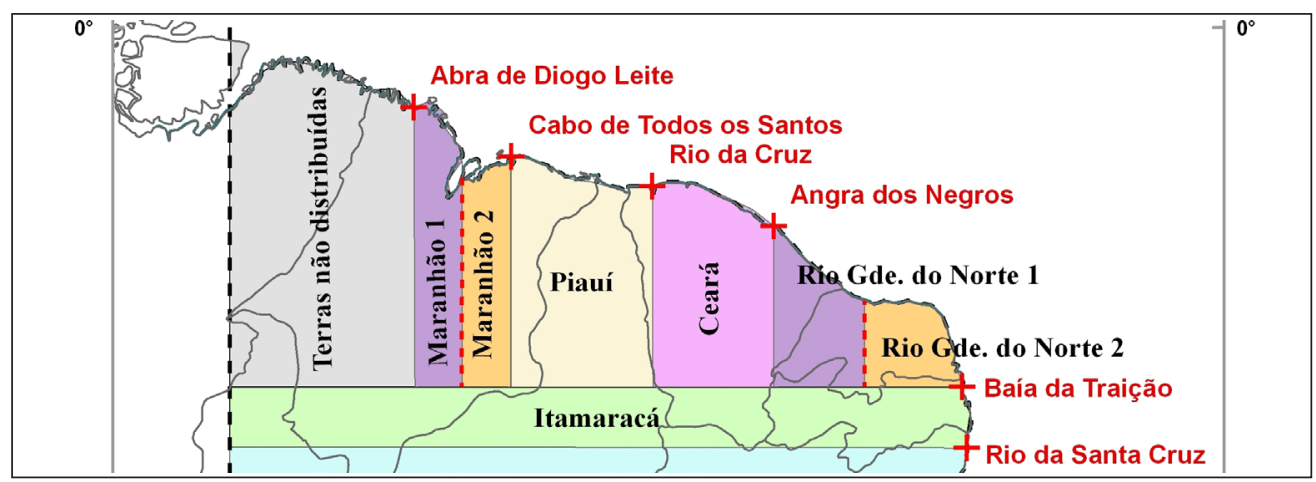

Figura 9 - Esquema das capitanias do norte. Desenho do autor.
47. Cf. Francisco Adolfo de Varnhagen (1956, p. 145)

48. Cf. Francisco Adolfo de Varnhagen (1956, p. 144).

Annals of Museu Paulista. v. 21. n.2. Jul.-Dec. 2013. 
49. Para isso fizemos o registro dos mapas em programa de cartografia digital e estudamos as longitudes. Também analisamos os topônimos (e sua quantidade) do Maranhão em direção à foz do Amazonas.
Na Tabela 7, para evitar a repetição dos nomes, indicou-se somente o limite a oeste; o limite a leste corresponde ao ponto oeste da capitania seguinte, e assim por diante até o último limite desse grupo de capitanias que é a Baia da Traição.

A identificação dos locais atuais é clássica para Camocim (Rio da Cruz) e para Angra dos Negros (Mucuripe); os autores, no entanto, variam na identificação do local da Abra de Diogo Leite: Varnhagen e alguns a identificam como a foz do Gurupi; outros, como Jaime Cortesão, d' Avezac e a solução do mapa tradicional do MEC, preferem a foz do Turiaçú. Para dirimir essa dúvida foram realizadas diversas medições em mapas da época: Diogo Homem (1558), Luis Teixeira (1568) e estudou-se ${ }^{49}$ a posição relativa dos diversos acidentes geográficos e todos os resultados apontam para ○ Turiaçú.

esquema clássico da divisão em capitanias propõe nomes para as mesmas que variam de autor para autor e correspondem, em geral, ao atual estado brasileiro que contém maior área dentro da capitania em exame. Obedecendo a esse mesmo critério, mas com as faixas correndo segundo os meridianos e não os paralelos, alguns nomes se modificam, como se vê na Figura 9.

\section{Tabela 7}

Donatários, léguas e limites com as capitanias vizinhas

\begin{tabular}{|c|c|c|c|c|c|}
\hline $\mathrm{n}$ & DONATÁRIO & SIGLA & LÉGUAS & LIMITE A OESTE & $\begin{array}{l}\text { LOCAL ATUAL / } \\
\text { INTERPRETACุÃO }\end{array}$ \\
\hline $1 \mathrm{~A}$ & Aires da Cunha & MA 1 & \multirow{2}{*}{50} & Abra de Diogo Leite & Rio Turiaçú \\
\hline $2 \mathrm{~A}$ & João de Barros & MA2 & & ponto médio & \\
\hline 3 & $\begin{array}{l}\text { Fernando Álvares de } \\
\text { Andrade }\end{array}$ & $\mathrm{PI}$ & 35 & $\begin{array}{l}\text { Cabo de Todos os Santos a } \\
\text { leste do rio Maranhão }\end{array}$ & $\begin{array}{c}\text { Iha de Santana (ponta a } \\
\text { oeste) }\end{array}$ \\
\hline 4 & $\begin{array}{l}\text { António Cardoso de } \\
\text { Barros }\end{array}$ & CE & 40 & Rio da Cruz & Camocim \\
\hline 1B & Aires da Cunha & RN1 & \multirow{2}{*}{100} & Angra dos Negros & Mucuripe \\
\hline $2 B$ & João de Barros & RN2 & & ponto médio & \\
\hline & Ponto mais ao sul & & & Baia de Traição & Baia de Traição \\
\hline
\end{tabular}

Como para os grupos anteriores, montou-se a Tabela 8, com o cálculo das léguas.

Tabela 8

Léguas de cada capitania:

na carta de doação, na realidade (testada) e na largura da faixa.

\begin{tabular}{|c|c|c|c|c|c|c|}
\hline \multirow{2}{*}{$\mathrm{n}$} & \multirow{2}{*}{ DONATÁRIO } & \multirow{2}{*}{ CAPITANIA } & \multicolumn{4}{|c|}{ LÉGUAS } \\
\hline & & & Doação & Testada & Dif. & Largura \\
\hline $1 \mathrm{~A}$ & Aires da Cunha & Maranhão 1 & \multirow{2}{*}{50} & \multirow{2}{*}{43,3} & \multirow{2}{*}{$-6,7$} & \multirow{2}{*}{30,0} \\
\hline $2 \mathrm{~A}$ & João de Barros & Maranhão 2 & & & & \\
\hline 3 & Fernando Álvares de Andrade & Piauí & 35 & 45,4 & 10,4 & 43,6 \\
\hline 4 & António Cardoso de Barros & Ceará & 40 & 40,8 & 0,8 & 37,6 \\
\hline 1B & Aires da Cunha & Rio Grande do Norte 1 & \multirow{2}{*}{100} & \multirow{2}{*}{87,3} & \multirow{2}{*}{$-12,7$} & \multirow{2}{*}{54,2} \\
\hline $2 B$ & João de Barros & Rio Grande do Norte 2 & & & & \\
\hline
\end{tabular}


resultado da medição das testadas aponta que a capitania 4 apresenta um valor muito próximo daquele da carta de doação. $\bigcirc$ da capitania $3(45,4)$ supera o valor estipulado, mas nada muito discrepante das diferenças ocorridas nas capitanias centrais e do sul. Isso de alguma maneira confirma o valor de 35 léguas; se fossem 75 como propõe Varnhagen ${ }^{50}$, baseado na leitura paleográfica do texto da Figura 6, a diferença seria de 29,6 léguas, erro bastante superior lquase três vezes) ao de qualquer outra capitania.

Sugestões para o desenho do mapa das capitanias hereditárias

Para desenhar o mapa completo sugere-se uma sequência de operações, que deve ser acompanhada pela Tabela 9. Nessa tabela, figura a sigla de duas letras para representar o nome da capitania, como se faz para os estados brasileiros, acrescentando um número quando necessário; essas já foram empregadas nas tabelas anteriores. Indica-se também o nome atual do limite somente a oeste ou ao norte, para evitar duplicações. A indicação da longitude e da latitude é o que permite desenhar o mapa, através dos seguintes passos:

1. Escolher um programa para Cartografia digital que permita trabalhar com projeções cartográficas;

2. Escolher uma projeção cartográfica. Sugere-se a Carta Plana Quadrada, em que os meridianos e os paralelos são retas igualmente espaçadas. Fica fácil demarcar os pontos, e o meridiano de Tordesilhas é uma reta. $\bigcirc$ Brasil fica ligeiramente deformado ao sul, como acontece com qualquer projeção, mas sem comprometer a identificação das formas;

3. Obter o contorno do Brasil no site do IBGE e também os limites interestaduais, caso se queira acrescentá-los;

4. Desenhar os limites do mapa: de $-30^{\circ}$ a $-60^{\circ}$ a oeste de Greenwich, em longitude e de $+10^{\circ}$ a $-30^{\circ}$ em latitude. Criar a rede de coordenadas geográficas: meridianos e paralelos de 10 em $10^{\circ}$ ou de 5 em $5^{\circ}$; evitando poluir o desenho. Incluir a linha de Tordesilhas com a longitude indicada no final dessa tabela; pode-se usar o estilo tracejado para transmitir incerteza na posição e sua fluidez como fronteira não demarcada;

5. Demarcar os pontos divisórios das capitanias na costa brasileira através das coordenadas fornecidas nessa tabela e acrescentar o nome do local lantigo ou atual: escolher);

6. Para as capitanias centrais, incluindo Itamaracá, traçar os paralelos por esses pontos, até a linha de Tordesilhas;

7. Traçar as divisórias das capitanias do sul, com particular atenção aos rumos noroeste na capitania de São Vicente, lote 11 A e suas vizinhas, até encontrar os paralelos $-21^{\circ}$ e $-23^{\circ}$;

8. Traçar as divisórias ao norte, passando pelos pontos fronteiriços e segundo meridianos, até encontrar o paralelo da capitania de ltamaracá; grafar terras não distribuídas (TND ou equivalente), entre o ponto mais a oeste (abra de Diogo Leite) 
e o meridiano de Tordesilhas. Escolher o padrão tracejado para dividir as capitanias de Aires da Cunha e João de Barros para indicar que deveria ser feita uma divisão entre eles;

9. Escolher adequadamente as cores para pontos, linhas e áreas (forte ou suave) e padrões de pontos e linhas (cruzetas, tracejado, espessura), segundo um projeto de comunicação cartográfica;

10. Acrescentar a toponímia que se considere oportuna. Escolher o que poderia constar nesse mapa para facilitar a leitura e compreensão: fronteira entre os estados (tracejado), siglas das capitanias, alguns rios mais importantes, pontos de limite, e o que se veja mais interessante.

11. Incluir legenda e notas; escolher o tipo de letra e posicionar adequadamente. Escolher as informações a constar: sigla da capitania, donatário, léguas.

resultado dessa metodologia é apresentado na tabela a seguir:

\section{Tabela 9}

Capitanias e seus limites (a oeste ou norte)

\begin{tabular}{|c|c|c|c|c|c|}
\hline $\mathrm{n}$ & SIGLA & DONATÁRIO & LIMITE (nome atual) & $\lambda$ & $\varphi$ \\
\hline $1 \mathrm{~A}$ & MAl & Aires da Cunha & Rio Turiaçú & 45,25 & 1,64 \\
\hline $2 \mathrm{~A}$ & MA2 & João de Barros & Ponto intermediário & 44,36 & 2,33 \\
\hline 3 & $\mathrm{Pl}$ & Fernando Álvares de Andrade & Ilha de Santana (oeste) & 43,75 & 2,36 \\
\hline 4 & CE & António Cardoso de Barros & Camocim & 40,85 & 2,87 \\
\hline $1 \mathrm{~B}$ & RN1 & Aires da Cunha & Mucuripe & 38,46 & 3,72 \\
\hline 2B & RN2 & João de Barros & Ponto intermediário & 36,66 & 5,08 \\
\hline $12 \mathrm{~A}$ & IT & Pero Lopes de Sousa & Baia da Traição & 34,93 & 6,68 \\
\hline 5 & PE & Duarte Coelho [Pereira] & Sul da I. de Itamaracá & 34,85 & 7,81 \\
\hline 6 & BA & Francisco Pereira Coutinho & Rio de São Francisco & 36,40 & 10,50 \\
\hline 7 & IL & Jorge de Figueiredo Correia & Sul da Baia de TS & 38,81 & 13,14 \\
\hline 8 & PS & Pedro do Campo Tourinho & Rio Pardo & 38,95 & 15,65 \\
\hline 9 & ES & Vasco Fernandes Coutinho & Rio Mucuri & 39,56 & 18,09 \\
\hline 10 & ST & Pero de Góis [da Silveira] & Rio Itapemirim & 40,81 & 21,00 \\
\hline $11 \mathrm{~A}$ & SV1 & Martim Afonso de Sousa & Rio Macaé & 41,78 & 22,38 \\
\hline $12 B$ & SA & Pero Lopes de Sousa & Rio Juquiriquerê & 45,43 & 23,71 \\
\hline $11 B$ & SV2 & Martim Afonso de Sousa & Barra da Bertioga & 46,13 & 23,86 \\
\hline \multirow[t]{3}{*}{$12 \mathrm{C}$} & ST & Pero Lopes de Sousa & Barra sul de Paranaguá & 48,36 & 25,55 \\
\hline & & Limite sul & $28^{\circ}$ e $1 / 3$ & 48,70 & 28,33 \\
\hline & & Linha de Tordesilhas & & 48,70 & \\
\hline
\end{tabular}


mapa da Figura 10, construído segundo esses princípios, é uma das materializações possíveis, podendo-se adequá-lo a diferentes finalidades, escolhendo as variáveis visuais que mais convenham.

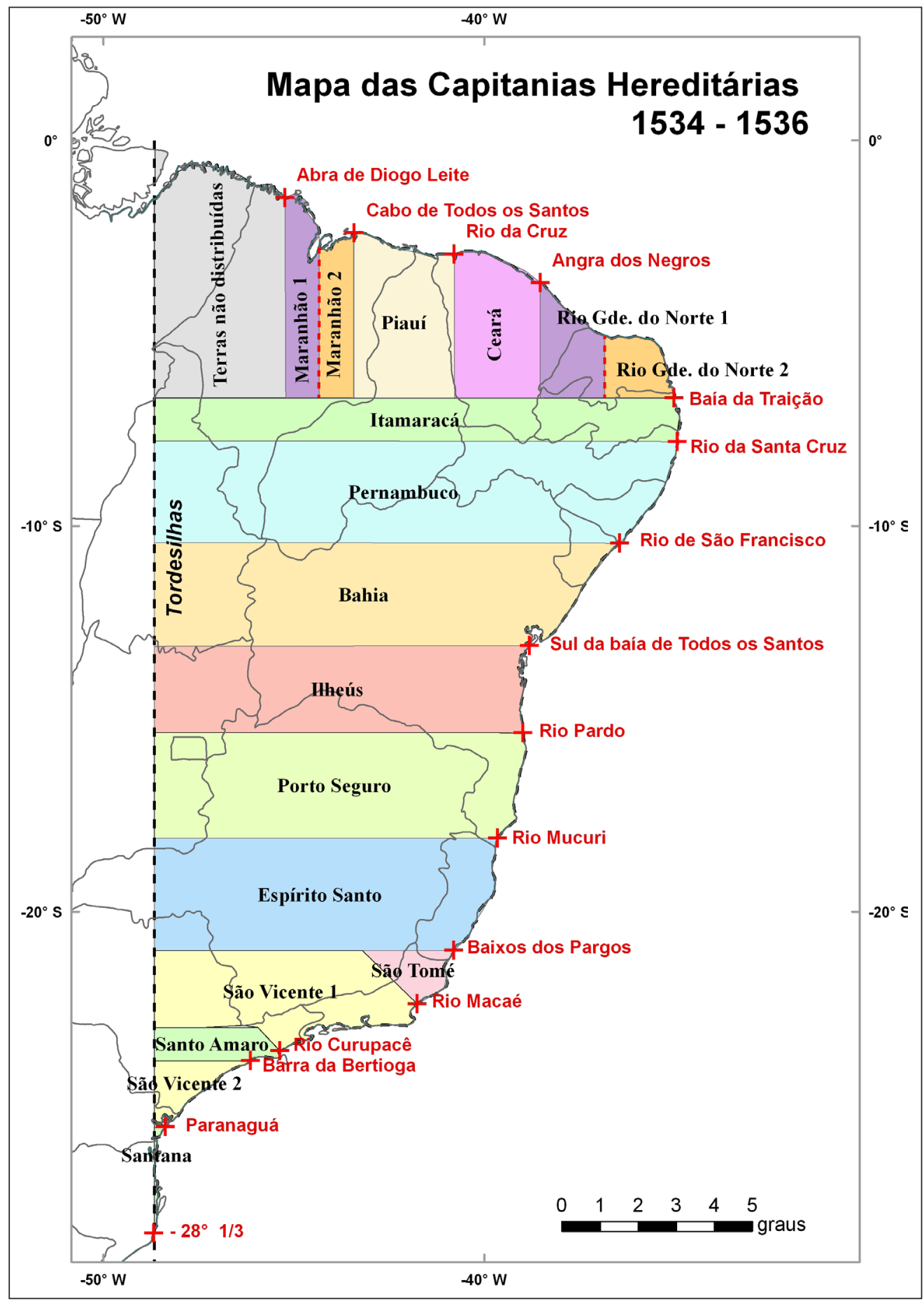

Figura 10 - Proposta do novo mapa das capitanias hereditárias. Desenho do autor. 
51. Francisco Adolfo de Varnhagen (1956, p. 147). Para a conversão de léguas quadradas (como fornece esse autor) para quilômetros quadrados, deve-se multiplicar o valor que ele fornece por 44,44, que resulta do valor do módulo de 16 2/3 léguas por grau. A porcentagem foi calculada subtraindo o novo valor do antigo, dividindo pelo novo e multiplicando por 100
De qualquer forma, existe um problema de escala: a limitação advém da largura útil da folha desta publicação; e o tamanho do mapa por sua própria natureza (largura, comprimento e legenda) é grande, o que obriga a uma escala cartográfica de poucos detalhes, ou seja, muita informação em pouco espaço, incluindo o problema do tamanho da letra e sua legibilidade. Os desenhos parciais, como os que foram feitos no presente trabalho permitem observar melhor os detalhes; mas a visão de conjunto sempre é necessária.

\section{Desdobramentos e continuidade}

Tendo em conta que no passado as áreas das capitanias foram calculadas $^{51}$, apresenta-se na Tabela 10 os cálculos feitos para a nova divisão proposta.

Tabela 10

Áreas das capitanias, comparando com o esquema tradicional

\begin{tabular}{|c|c|c|c|c|}
\hline \multirow[b]{2}{*}{$\mathrm{n}$} & \multirow[b]{2}{*}{ DONATÁRIO } & \multicolumn{2}{|c|}{ ÁREAS } & \multirow{2}{*}{$\begin{array}{c}\text { DIFERENÇA EN } \\
\%\end{array}$} \\
\hline & & $\begin{array}{l}\text { Esquema } \\
\text { tradicional }\end{array}$ & $\begin{array}{l}\text { Esquema } \\
\text { proposto }\end{array}$ & \\
\hline * & Terras não distribuídas (coroa) & 25 & 241 & $-90 \%$ \\
\hline 1 & Aires da Cunha & 289 & 98 & $195 \%$ \\
\hline 2 & João de Barros & 289 & 77 & $275 \%$ \\
\hline 3 & Fernando Álvares de Andrade & 67 & 127 & $-48 \%$ \\
\hline 4 & António Cardoso de Barros & 27 & 97 & $-73 \%$ \\
\hline 5 & Duarte Coelho [Pereira] & 533 & 425 & $25 \%$ \\
\hline 6 & Francisco Pereira Coutinho & 311 & 358 & $-13 \%$ \\
\hline 7 & Jorge de Figueiredo Correia & 311 & 258 & $21 \%$ \\
\hline 8 & Pedro do Campo Tourinho & 289 & 309 & $-7 \%$ \\
\hline 9 & Vasco Fernandes Coutinho & 244 & 291 & $-16 \%$ \\
\hline 10 & Pero de Góis [da Silveira] & 89 & 22 & $304 \%$ \\
\hline 11 & Martim Afonso de Sousa & 111 & 172 & $-35 \%$ \\
\hline \multirow[t]{2}{*}{12} & Pero Lopes de Sousa & 333 & 228 & $46 \%$ \\
\hline & Área total $=$ & 2918 & 2703 & $8 \%$ \\
\hline
\end{tabular}


A área total apresenta uma diferença de $8 \%$, que é relativamente pequena, tendo em conta que o cálculo no esquema tradicional foi feito de forma arredondada e não se possuí detalhes a respeito de como foi tratada a questão da projeção cartográfica, que causa deformação nas distâncias e nas áreas. $\bigcirc$ cálculo atual foi feito com a ajuda de um programa para cartografia digital que avalia a área de cada polígono (capitania) por meio de calotas esféricas. Era de esperar grandes diferenças nas capitanias do norte ( 1 a 4) e também nas do sul ( 10 a 12), com maior disparidade na 10, por sua redução de tamanho; mas as diferenças deveriam ser um pouco menores nas capitanias centrais (5 a 9), quando comparada a diferença de cada uma com a diferença obtida para a área total (8\%).

De qualquer forma, o dado sobre a área não parece ter tanta relevância nesses primórdios, pois havia terras em abundância e seriam mais relevantes a testada na costa, os bons portos, a qualidade do solo e o relacionamento com os índios da terra. No entanto, não obstante a ocupação de somente uma estreita faixa ao longo do litoral e a pouca penetração, a existência de maiores ou menores fundos poderia ter influência no futuro desenho do território.

Outra continuidade natural é aprofundar no estudo de como foi a evolução das linhas divisórias entre as capitanias, passando pela criação de novas, inclusive além da linha de Tordesilhas, aquisições por parte da coroa, aglutinações, desmembramentos, retificação de rumos, até chegar à extinção total do sistema. A evolução natural levaria a analisar também o impacto da morfologia das capitanias na formação das fronteiras dos atuais estados brasileiros e as pendências que se arrastaram por muito tempo.

Outro aspecto relevante é a metamorfose das linhas divisórias: como passaram de linhas retas desenhadas no papel para polígonos seguindo os acidentes naturais: rios, divisores de água e outros, que foram também a base dos tratados internacionais, como o de Madri.

Créditos a um trabalho desconhecido

É necessário dizer que existem alguns trabalhos que, sem se aprofundarem muito, mostram as linhas de rumo noroeste nas capitanias do sul, baseados nas cartas de doação dos irmãos Sousa.

Merece um destaque à parte o interessantíssimo trabalho de Alberto Gallo52, do qual só se teve conhecimento ao término da presente pesquisa. Sem um enfoque cartográfico, apresenta, com antecedência, muitos acertos e coincidências com o presente trabalho: o uso de mapas como o Mapa proposto por Varnhagen, a Carta geral do Brasil e o de Bartolomeu Velho (Figuras 2, 3 e 7); a crítica à doação conjunta ou em condomínio de capitanias e a correta interpretação da carta de mineração. Acerta também na particular direção de algumas linhas divisórias ao sul e, de forma geral, na direção dos limites ao norte. Sua proposta fundamental é que as linhas divisórias eram perpendiculares à costa, o que o leva erroneamente a estabelecer uma linha sudoeste ao norte, passando aproximadamente pelo cabo
52. Ver Alberto Gallo (1999). 
de São Roque e criando duas capitanias triangulares para João de Barros e Aires da Cunha.

Essa tese do perpendicularismo, na qual insiste reiteradamente, poderia ser somente uma aproximação, uma primeira idéia geral para o cartógrafo, que pode ser válida, grosso modo, para mapas em escala geral, mas não em pontos da recortada costa brasileira, que pode tomar um rumo bem diferente da direção geral; o correto seria ater-se à letra das cartas de doação e estabelecer direções segundo os rumos principais: leste-oeste, noroeste, norte-sul.

Outra novidade foi utilizar o mapa de Gaspar Viegas (1534-1536), que de fato consigna a toponímia da viagem de Martim Afonso. Mas essa adoção tem dois inconvenientes principais. $\bigcirc$ primeiro é fornecer uma visão pouco reconhecível do Brasil, dos Estados e da posição dupla da linha de Tordesilhas. $\bigcirc$ segundo é que, apesar de reconhecer posteriormente a possibilidade de haver uma grande distensão da costa norte brasileira, não a levou em consideração em seus cálculos. Efetivamente, afirma que, nesse protótipo, as léguas das capitanias dessa região coincidem ao milímetro com os valores das cartas de doação. Para verificar essa afirmação, foram feitas diversas medições sobre esse mapa, seguindo a metodologia já apresentada. $\bigcirc$ resultado é: 86 léguas para o território de 50, de Aires da Cunha e João de Barros; 82 léguas para as 35 de Fernando Álvares de Andrade; 36 para as 40 de António Cardoso de Barros e 144 para as 100 léguas do segundo território de Aires da Cunha e João de Barros. Ou seja, não coincidem ao milímetro com os valores da carta de doação. Esse mapa transfere às capitanias do norte a distorção da costa brasileira. Em função disso, não acerta na posição relativa entre os Estados brasileiros atuais e as capitanias e propõe nomes inadequados para elas. Para que se tenha uma idéia das variações desse mapa, a diferença de longitude entre o cabo de Santo Agostinho e a abra de Diogo Leite, ao norte, nesse documento, é 16,90\%, quando na realidade é de 10,3 (dilatação de 6,6\%); e a diferença de longitude entre esse mesmo cabo e Laguna, ao sul, nessa cartografia é de $13,8^{\circ}$, quando na realidade é de $10,6^{\circ}$ (dilatação de $3,2^{\circ}$ ). Isso mostra uma distorção ou dilatação diferencial ao norte de $3,4^{\circ}\left(6,6^{\circ}-3,2^{\circ}\right)$.

Acerta em alguns pontos na crítica ao visconde de Porto Seguro, mas admite as 75 léguas para a capitania de Fernando Álvares de Andrade e às vezes ultrapassa o limite do razoável, propondo para esse autor intenções e motivações demasiado sutis ou sibilinas, como depois reconhece.

Apesar de tudo, o resultado desse trabalho, publicado há uns 15 anos, anuncia, em linhas gerais e como hipótese, um novo desenho das capitanias. Mas, por que não teve difusão entre nós? Talvez por ter sido publicado no exterior e não no Brasil, numa revista em papel, não assinada por biblioteca brasileira.

Ao tomar conhecimento desse artigo, havia a opção de começar por resumi-lo e apontar erros e acertos. Mas, dada sua natureza pouco sistemática, seu ir e vir, apresentar uma grande quantidade de hipóteses e temas paralelos, 
além de explicações complicadas, pareceu-me mais produtivo para o leitor construir, passo a passo e de forma mais sistemática e focada, o mapa das capitanias, com base nos documentos disponíveis, ou seja, unindo a cartografia às fontes textuais.

\section{Considerações finais}

Como se pôde ver, esteve-se trabalhando sempre às luzes e sombras de Varnhagen. Para dar um passo além, foi necessário aprofundar nos textos originais das cartas de doação e forais, contando também com o auxílio da cartografia histórica e digital, o que permitiu sugerir diversas modificações ao padrão atual. Foi feita uma proposta cartográfica, como alternativa ao modelo proposto por esse autor há mais de 150 anos. Mais do que concluir, espera-se ter contribuído para abrir novos debates sobre o tema.

\section{REFERÊNCIAS}

ABREU, Capistrano de. Nota. In: VARNHAGEN, Francisco Adolfo de. História geral do Brasil, $5^{\text {a }}$ ed. da obra, 6a. do vol. I. São Paulo: Melhoramentos, 1956.

ABREU, Capistrano de. Prolegômenos. In: SALVADOR, Frei Vicente do. História do Brasil, L.II. São Paulo: Melhoramentos, 1954.

ALBUQUERQUE, Manoel Maurício de. As primeiras capitanias hereditárias [mapa]. In: ALBUQUERQUE, Manoel Maurício de et al. Atlas histórico escolar, 7a. ed. Rio de Janeiro: Fundação Nacional de Material Escolar; Ministério da Educação e Cultura, 1977, p. 16.

BAIÃO, António. Introdução. In: BARROS, João de. Ásia, de João de Barros. Coimbra: Imprensa da Universidade, 1988 [fac-símile da edição de 1932].

CARTA de doação a Pero Lopes. Documentos históricos da Biblioteca Nacional, v. 13. Rio de Janeiro: Biblioteca Nacional, 1929.

CARTA de doação a Pero Lopes. Documentos históricos da Biblioteca Nacional, v. 80. Rio de Janeiro: Biblioteca Nacional, 1948.

CARTA de mineração. CHR-L-1-21_c0151: ANTT, Chancelaria Régia, D. João III, Livro21, folha 73. Arquivo da Torre do Tombo, Lisboa.

CARTA do Mestre João. Disponível em: <http://pt.wikipedia.org/wiki/Carta_do_Mestre_ João>, acesso em 01/06/2013.

CARVAlHO, Joaquim Barradas de. Esmeraldo de Situ Orbis de Duarte Pacheco Pereira. Lisboa: Fundação Calouste Gulbenkian, 1991.

CHORÃO, Maria José Mexia Bigotte. Doações e forais das capitanias do Brasil (1534-1536). Lisboa: Instituto dos Arquivos Nacionais / Torre do Tombo, 1999. 
CINTRA, Jorge Pimentel. O Mapa das Cortes e as fronteiras do Brasil. Boletim de Ciências Geodésicas, Curitiba, v. 18, no 3, p. 421-445, jul.-set., 2012.

CORTESÃO, Armando. Cartografia portuguesa antiga. Lisboa: Comissão Executiva das Comemorações do Quinto Centenário da Morte do Infante D. Henrique, 1960.

CORTESÃO, Jaime História do Brasil nos velhos mapas, 2 tomos. Lisboa: Imprensa NacionalCasa da Moeda, 2009.

CORTESÃO, Jaime. A fundação de São Paulo, capital geográfica do Brasil. Rio de Janeiro: Livros de Portugal, 1955.

CORTESÃO, Jaime. História do Brasil nos velhos mapas, tomo I. Rio de Janeiro: Ministério das Relações Exteriores, Instituto Rio Branco, 1965.

DIAS, Carlos Malheiro (coord.). História da colonização portuguesa do Brasil. Porto: Litografia Nacional, 1921.

GALLO, Alberto. La divisione del Brasile nel 1534-1534. Una nuova ipotesi. Annnali della fondazione Luigi Einaldi, Turim, v.33, p. 323-364, 1999.

GASPAR, Joaquim Alves. From the Portulan Chart of the Mediterranean to the Latitude Chart of the Atlantic. Tese (Doutorado), Universidade de Nova Lisboa, Lisboa, 2010.

IBGE - Carta do Brasil ao milhonésimo, $3^{\text {a }}$ ed. (1999), disponível em: <http://mapas.ibge.gov. br/>, acesso em 01/06/2013.

LAMEGO, Alberto. Mentiras históricas. Rio de Janeiro: Record, s/d.

LEME, Pedro Taques de Almeida Pais. História da capitania de São Vicente. Brasília: Senado Federal, 2004 [1772]. Disponível em: http://www.bibliotecavirtual.sp.gov.br/pdf/saopaulohistoriadacapitaniasaovicente.pdf, acesso em 01/06/2013.

MADRE DE DEUS, Frei Gaspar da. Memórias para a história da Capitania de São Vicente. Belo Horizonte: Itatiaia; São Paulo: EDUSP, 1975.

MADRE DE DEUS, Frei Gaspar. Memórias para a história da Capitania de São Vicente, hoje chamada de São Paulo. Lisboa, Typografia da Academia, 1797. Disponível em: <http://books. google.com.br/books>, acesso em 01/06/2013.

MARQUES, A.P.. Regimento das léguas. In: ALBUQUERQUE, Luís de (dir.). Dicionário de bistória dos Descobrimentos. Vol. II. Lisboa: Círculo de Leitores, 1994.

MORAES, Abrão de. A astronomia no Brasil. São Paulo: EDUSP; Instituto Astronômico e Geofísico, 1984.

MOTA, Avelino Teixeira da; CORTESÃO, Armando. Portugaliae Monumenta Cartographica. Lisboa: Imprensa Nacional, Casa da Moeda, 1960.

OLIVEIRA, Cêurio. Dicionário cartográfico. Rio de Janeiro: IBGE, 1980.

RIBEIRO, Diego (1529). Carta universal. Mapa e texto que podem ser encontrados em $<$ http://www.henry-davis.com/MAPS/Ren/Ren1/346mono>, acesso em 01/06/2013. 
RIBEIRO, Diogo. Mapa (1529). Disponível em: <http://www.henry-davis.com/MAPS/Ren/ Ren1/346mono>, acesso em 01/06/2013.

SOUSA, António Caetano de. Provas de história genealógica da casa real portuguesa, v. VI. Lisboa: Oficina Sylviana da Academia Real, 1739. Disponível em <http://books.google.pt/>, acesso em 01/06/2013.

VARNHAGEN, Francisco Adolfo de. História geral do Brasil, $6^{\mathrm{a}}$ ed, vol. I. São Paulo: Melhoramentos, 1956.

VARNHAGEN, Francisco Adolfo de. História geral do Brazil, $1^{\text {a }}$ ed., vol. I, Rio de Janeiro: Laemmert, 1854. Disponível em: http://www.brasiliana.usp.br/bbd/ handle/1918/01818710\#page/7/mode/1up, acesso em 01/06/2013.

VIEGAS, Gaspar. Mapa (1534). Disponível em: <http://objdigital.bn.br/objdigital2/acervo_ digital/div_cartografia/cart376284/cart376284.jpg>, acesso em 01/06/2013.

Artigo apresentado em 06/06/2013. Aprovado em 29/11/2013. 